\title{
Az elérhető és a kapott információk megbízhatóságának és hitelességének megítélése a NAV munkatársai által
}

\section{DUCHON Jenö ${ }^{1}$}

\begin{abstract}
Az informatika mindennapjaink meghatározó részévé vált, az információt közvetítő eszközök mindannyiunk életét átszövik. Minden felhasználó egyéni felelőssége, hogy az információt tudatosan kezelje. Az információ tudatos felhasználása a kezelt információk okán különösen nagy jelentőséggel bír a Nemzeti Adó- és Vámhivatal munkatársai esetén. A NAV munkatársai körében kérdőives kutatás segítségével lezajlott egy attitǔdvizsgálat, amelyben szerepet kapott a munkatársak különböző informatikai eszközökön elérhető, illetve a különböző eszközökön keresztül kapott információk hitelességének és megbizhatóságának a megítélése. Jelen tanulmány ennek a felmérésnek az eredményeit összegzi annak érdekében, hogy a feltárt kép alapul szolgáljon egy komplex információbiztonság-tudatosságot fejlesztő program kidolgozásában és bevezetésében.
\end{abstract}

Kulcsszavak: információhitelesség, információmegbizhatóság, információbiztonság-tudatosság, attitüdvizsgálat

\section{Bevezetés}

A mindennapi életünket egyre nehezebb elképzelnünk a minket körülvevő informatikai eszközök nélkül, amelyek tárolják, továbbítják, esetleg feldolgozzák a kapott információkat. Nem véletlen tehát, hogy jelen korunkat az információs társadalom korának szoktuk nevezni. Az információs társadalomban maga az információ és a hozzá kapcsolódó jelenségek, mint a kommunikáció, az adatgyưjtés, az adatfeldolgozás, a korábbinál sokkal központibb szerepbe kerülnek, és jelentősen meghatározzák az emberi kapcsolatokat, a kultúrát, az állami és más szervezetek múködését, a tér és idő fogalmát, rögzítettségét. ${ }^{2}$ Amennyiben az információ érték, úgy arra bizony vigyáznunk kell. Jóléti társadalmunkban minden egyes egyénnek felelőssége van abban, hogy megtanulja és képes legyen kezelni a különböző közműrendszereket (például víz, gáz, elektromos

DUCHON Jenő, osztályvezető, Nemzeti Adó- és Vámhivatal Képzési, Egészségügyi és Kulturális Intézete, Fejlesztési és Módszertani Főosztály, Működtetési Képzési és Oktatástechnológiai Fejlesztési Osztály Jenő DUCHON, Head of Division, National Tax and Customs Administration Training Healthcare and Cultural Institute, Department for Development and Methodology, Operational Educational and Training Technology Development Unit

https://orcid.org/0000-0001-6931-2828; duchon.jeno@nav.gov.hu

2 Pintér 2007, 21-22. 
áram). Napjainkban az információ is része a közműrendszernek. Ebből következik, hogy minden egyes polgárnak ki kell alakítania a tudatos információs eszközhasználatot, amelynek része az információbiztonsággal kapcsolatos ismeretek bővítése, a biztonságtudatos attitűd kialakítása. ${ }^{3}$

\section{Információbiztonság}

A 2013. évi L. törvény a következőképpen definiálja a biztonsági eseményt: „Olyan nem kívánt vagy nem várt egyedi esemény vagy eseménysorozat, amely az elektronikus információs rendszerben kedvezőtlen változást vagy egy előzőleg ismeretlen helyzetet idéz elő, és amelynek hatására az elektronikus információs rendszer által hordozott információ bizalmassága, sértetlensége, hitelessége, funkcionalitása vagy rendelkezésre állása elvész, illetve megsérül." Ebből következik, hogy az információ rendelkezik egy olyan állapottal, amelyből kibillentve biztonsági esemény jön létre. Annak érdekében, hogy ezt a biztonságos állapotot fenntartsuk, szükségessé válik az információ védelme, amelynek során az alábbi tevékenységköröket végezzük: megelőzés, észlelés, reagálás, eseménykezelés. ${ }^{4}$

\section{Információbiztonság-tudatosság kialakítása az információ védelme érdekében}

Az információ biztonságos állapota fenntartásának része a megelőzés, amelynek során kiemelten fontos a felhasználóknál a megfelelő biztonságtudatos attitűdök kialakítása. Ennek érdekében tudatos lépéseket kell tenni éppen úgy a magánéletben, mint a NAVon belül. A biztonságtudatos viselkedés kialakítása érdekében szükség lehet az információbiztonsági ismeretek oktatására, azonban a biztonságtudatos viselkedés, illetve attitűd kialakítása nem merülhet ki a vonatkozó ismeretek átadásában, elsajátításában, számonkérésében. A cél minden esetben az, hogy kialakuljon egy olyan viselkedésnorma, amely esetén az egyén képessé válik arra, hogy figyelmet fordítson az információbiztonságra, képes legyen észlelni azt és érzékelni az IT-biztonsággal kapcsolatos veszélyeket, problémákat, és azokra tudatosan tudjon is reagálni. ${ }^{5} \mathrm{~A}$ biztonságtudatosság fejlesztése érdekében lehetőségünk van meglévő programok átvételére vagy egyedi program kidolgozására is. ${ }^{6}$ Bármelyik utat is választjuk, minden esetben szükségessé válik az aktuális állapot felmérése.

\footnotetext{
Nyikes (2016)

Muha (2008)

Wilson-Hash (2003)

Khan et al. (2011)
} 


\section{Információbiztonság-tudatosság felmérése kérdőives módszerrel}

Az információbiztonság-tudatosság vizsgálatát többféleképpen is elvégezhetjük. Vizs-

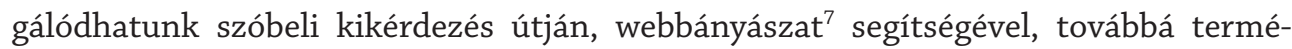
szetesen a kérdőívtechnika alkalmazásával. Ez utóbbi esetén számos olyan kérdőívet adaptálhatunk, amely a kutatásunk során felhasználható. ${ }^{8}$ Sajnos ezek a kérdőívek a magánszférában vagy a civil munkahelyi környezetben (hisz a NAV is egy munkahelyi környezet, igaz, ez esetben állami szektorról van szó) vizsgálják az egyének biztonságtudatosságát. Ezért a hivatalon belüli állapotfelmérés érdekében egy egyedi kérdőívet dolgoztunk ki, amelyben több oldalról is felmértük a válaszadók biztonságtudatossággal kapcsolatos attitűdjét. Ennek része volt az információ hitelességét és megbízhatóságát vizsgáló kérdések.

\section{A minta jellemzői}

A kutatás online környezetben zajlott, amelynek során a kérdőívet 928-an töltötték ki. A vizsgálatban résztvevők 53,34\%-a (495 fő) volt nő, 46,66\%-a (433 fő) pedig férfi. A nemek aránya közel egyenlő volt.

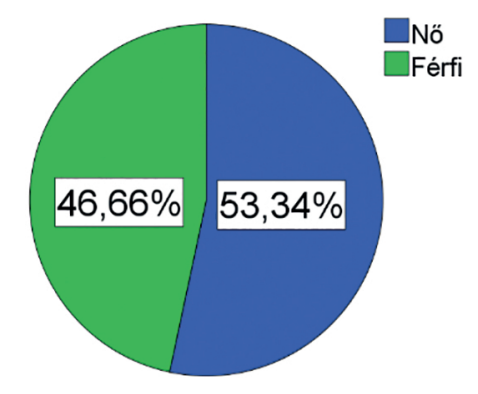

\begin{tabular}{|l|c|c|c|}
\hline & Gyakoriság & Relatív gyakoriság & Relatív kumulatív gyakoriság \\
\hline Férfi & 495 fö & $53,3 \%$ & $53,3 \%$ \\
\hline Nő & 443 fő & $46,7 \%$ & $100,0 \%$ \\
\hline Összesen & 928 fő & $100 \%$ & \\
\hline
\end{tabular}

1. ábra: A kérdőívet kitöltő NAV-munkatársak nemi megoszlása $(n=928)$. Forrás: a szerző szerkesztése

\footnotetext{
A webbányászat alapvetően három témakört ölel magába: információs tartalom vizsgálata, információs struktúra vizsgálata és az információ felhasználásának vizsgálata. Többek között az információs rendszerek naplóállományainak adatfeldolgozása az utóbbiba sorolható, amely adatok feldolgozásával, elemzésével nagy mennyiségú adathalmazból nem kézenfekvő, értékes információk nyerhetők a felhasználók információs közegben történő viselkedésével kapcsolatosan. Desikan et al. (2006); Klösgen-Zytkon (2002)

8 Security Awareness Planning Kit (2016); Survey on Internet Security Awareness (2009)
} 
Érdemes megnézni a válaszadók életkori sajátosságait is. Az átlag életkor 44 év, a legidősebb válaszadó 69 éves (1 fő), a legfiatalabb pedig 24 éves (3 fő) volt.

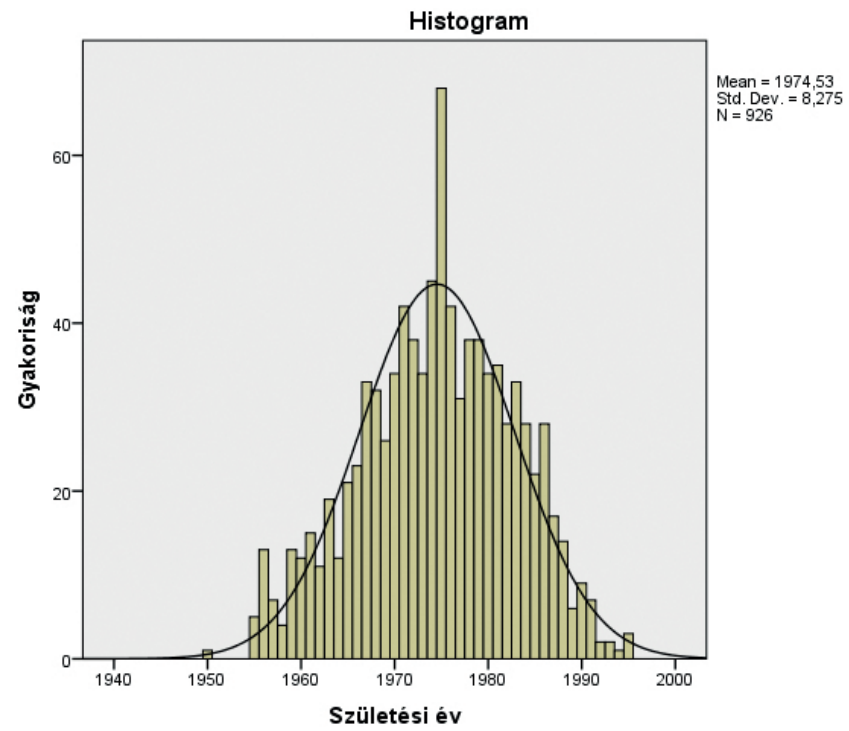

2. ábra: A kérdőivet kitöltő NAV-munkatársak születési évének gyakoriságeloszlása ( $n$ =926). Forrás: a szerző szerkesztése

Fontosnak tartottuk a mintát generációelméleti alapon is megvizsgálni. ${ }^{9}$

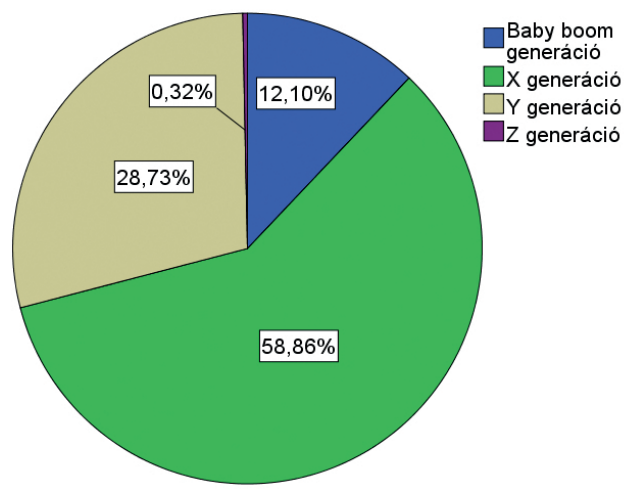

\begin{tabular}{|l|c|c|c|}
\hline & Gyakoriság & Relatív gyakoriság & Relatív kumulativ gyakoriság \\
\hline Baby boom generáció & 112 fő & $12,1 \%$ & $12,1 \%$ \\
\hline X generáció & 545 fő & $58,9 \%$ & $71,0 \%$ \\
\hline
\end{tabular}

9 Tari (2010); Kissné András (2014); Meretei (2017) 
DUCHON Jenő: Az elérhető és a kapott információk megbízhatóságának és hitelességének megítélése...

\begin{tabular}{|l|c|c|c|}
\hline & Gyakoriság & Relativ gyakoriság & Relatív kumulatív gyakoriság \\
\hline Y generáció & 266 fő & $28,7 \%$ & $99,7 \%$ \\
\hline Z generáció & 3 fô & $0,3 \%$ & $100,0 \%$ \\
\hline Összesen & 928 fő & $100 \%$ & \\
\hline
\end{tabular}

3. ábra: A kérdöívet kitöltő NAV-munkatársak generációelméleti megoszlása ( $n=928)$.

Forrás: a szerző szerkesztése

Feltételezhetjük: információbiztonság-tudatosság szempontjából fontos befolyásoló tényező, hogy a kitöltő rendelkezik-e informatikai végzettséggel vagy sem. A mintában szereplő adatok alapján a kérdőív kitöltőinek 78\%-a nem informatikai végzettségú, tehát a válaszadóknak közel negyede rendelkezett csak valamilyen informatikai végzettséget igazoló bizonyítvánnyal (középfokú végzettség: 12,6\%; felsőfokú végzettség: $9,4 \%)$.

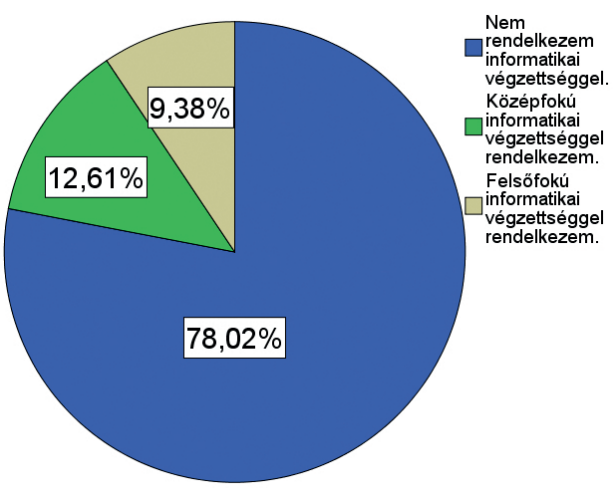

\begin{tabular}{|l|c|c|c|}
\hline & Gyakoriság & Relatív gyakoriság & $\begin{array}{c}\text { Relatív kumulatív } \\
\text { gyakoriság }\end{array}$ \\
\hline $\begin{array}{l}\text { Nem rendelkezem informatikai } \\
\text { végzettséggel }\end{array}$ & 724 fő & $78,0 \%$ & $78,0 \%$ \\
\hline $\begin{array}{l}\text { Középfokú informatikai végzettséggel } \\
\text { rendelkezem }\end{array}$ & 117 fő & $12,6 \%$ & $90,6 \%$ \\
\hline $\begin{array}{l}\text { Felsőfokú informatikai végzettséggel } \\
\text { rendelkezem }\end{array}$ & 87 fő & $9,4 \%$ & $100,0 \%$ \\
\hline Összesen & 928 fő & $100 \%$ & \\
\hline
\end{tabular}

4. ábra: A kérdőivet kitöltő NAV-munkatársak informatikai végzettség szerinti megoszlása (n =928). Forrás: a szerzô szerkesztése 
Amennyiben biztonsággal kapcsolatos attitűdöt vizsgáljuk, fontos lehet a számunkra megnézni azt is, hogy a nagyobb döntési felelősséggel rendelkező vezetői munkakörökben dolgozók, illetve az ügyintézők válaszai között észlelhetünk-e eltérést. A beérkezett adatok alapján a válaszadók többsége (762 fő; 82,11\%) beosztottként dolgozik, és csak a fennmaradó (166 fő; 17,9\%) tevékenykedik vezetői munkakörben.

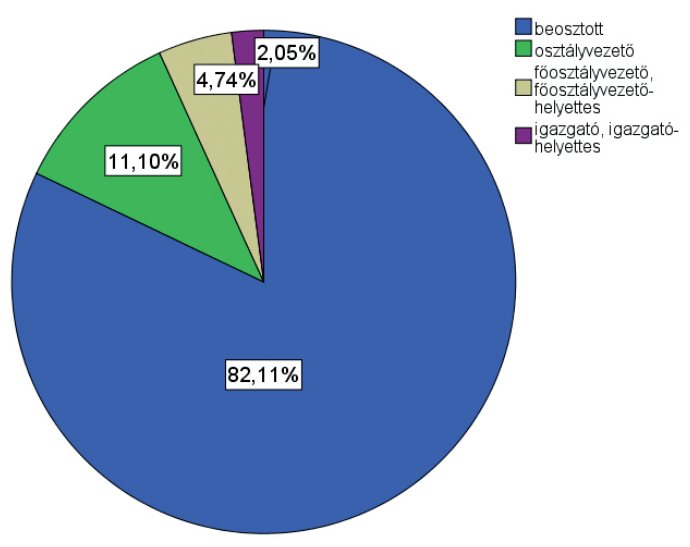

\begin{tabular}{|l|c|c|c|}
\hline & Gyakoriság & Relatív gyakoriság & $\begin{array}{c}\text { Relatív kumulatív gyako- } \\
\text { riság }\end{array}$ \\
\hline beosztott & 726 fổ & $82,1 \%$ & $82,1 \%$ \\
\hline osztályvezető & 103 fổ & $11,1 \%$ & $93,2 \%$ \\
\hline $\begin{array}{l}\text { főosztályvezető, főosztályvezető- } \\
\text { helyettes }\end{array}$ & 44 fő & $4,7 \%$ & $98,0 \%$ \\
\hline igazgató, igazgató-helyettes & 19 fő & $2,0 \%$ & $100,0 \%$ \\
\hline Összesen & 928 fố & $100,0 \%$ & \\
\hline
\end{tabular}

5. ábra: A kérdőívet kitöltő NAV-munkatársak munkahelyi hierarchia szerinti megoszlása (n =928). Forrás: a szerző szerkesztése

\section{Az információ hitelességének, illetve megbizhatóságának vizsgálata}

Egy felhasználó az információhoz vagy valamely információforrás elérésével, vagy mások által a számára történő rendelkezésre bocsátásával jut hozzá. Természetesen mind a két út esetén külön meg kell vizsgálnunk, hogy az adott információforrást ki biztosítja. 
1. táblázat: A vizsgált információforrások és a kapcsolódó személyek. Forrás: a szerző szerkesztése

\begin{tabular}{|c|c|c|}
\hline & Információ forrása & Információt biztosító személy vagy szerv \\
\hline & weboldal, információs felület & $\begin{array}{c}\text { ismeretlen személy } \\
\text { hivatalos szerkesztő } \\
\text { ismerôs személy } \\
\text { munkahelyi szerkesztő }\end{array}$ \\
\hline & e-mail & $\begin{array}{c}\text { ismeretlen személy } \\
\text { hivatalos szerv vagy cég } \\
\text { ismerős személy }\end{array}$ \\
\hline & üzenetküldő szolgáltatás & $\begin{array}{c}\text { munkahelyi közvetlen/nem közvetlen munkatárs } \\
\text { munkahelyi nem közvetlen munkatárs } \\
\text { munkahelyi közvetlen/nem közvetlen vezető } \\
\text { munkahelyi felsővezetô }\end{array}$ \\
\hline
\end{tabular}

Az egyes információforrások esetén a kérdőív kitöltőinek egy 1-5 értékű skála (1 - egyáltalán nem értek egyet; 5 - teljesen egyetértek) segítségével kellett megválaszolniuk, hogy mennyire értenek egyet azzal a kijelentéssel, hogy az egyes információ-hozzáférési módokon elérhető tartalmakban megbíznak, azok nem jelentenek fenyegetést számukra, illetve az egyes hozzáférési módokon elérhető tartalmak számukra a valóságnak megfelelő, hiteles információval szolgálnak.

A kérdőív kiértékelése során megállapítottuk a kapott válaszok átlagát, illetve korrelációs vizsgálat segítségével megvizsgáltuk az egyes változók közötti kapcsolat szorosságát. ${ }^{10}$

2. táblázat: Korrelációs együtthatók értelmezése a kapcsolat erôssége szerint jelen tanulmányon belül. Forrás: a szerzô szerkesztése

\begin{tabular}{|c|c|}
\hline Korrelációs együttható értéke & Korrelációs kapcsolat erössége \\
\hline$r=|1|$ & Tökéletes kapcsolat \\
\hline$|1|>r>=|0,7|$ & Erős kapcsolat \\
\hline$|0,7|>r>=|0,3|$ & Közepes kapcsolat \\
\hline$|0,3|>r>=0$ & Gyenge kapcsolat \\
\hline$r=0$ & Nincs kapcsolat \\
\hline
\end{tabular}

Végezetül nem paraméteres próbát felhasználva megvizsgáltuk, hogy mely válaszok esetén találtunk szignifikáns különbséget az informatikai végzettséggel rendelkezők és az azzal nem rendelkezők, a vezetők és a beosztottak, illetve az egyes generációk

10 Hollik-Ősz (2016) 
mintái között. Minden minta esetében előzetesen megnéztük és kiértékeltük, hogy az adott minta normáleloszlású-e. Mivel a változók normalitásvizsgálata során el kellett vetni azt a hipotézist, hogy azok normáleloszlásúak, így a kétmintás esetben a minták összevetésekor a Mann-Whitney-próbát, a többmintás esetben pedig a Kruskal-Wallis-próbát is elvégeztük. Mindkét próba nullhipotézise kimondja, hogy a független minták szignifikánsan nem különböznek egymástól, amennyiben p > 0,05. Ellenkező esetben elvetjük a nullhipotézist, azaz a minták szignifikánsan eltérők.

\section{Az elérhető tartalmak megbízhatóságának, illetve hitelességének megítélése}

A válaszadók, függetlenül az információforrás szerkesztőjétől, az információforrás által biztosított tartalmakban megbíznak, ezért nem érzik úgy, hogy azok fenyegetést jelentenének a számukra. Ugyanakkor az adott felületeken elérhető tartalmakat már sokkal kevésbé tartják hitelesnek. Jól látható, hogy leginkább a munkahelyi környezetben elérhető információs felületeket tartják a legbiztonságosabbnak $(4,43)$, de magával az információ hitelességével kapcsolatosan még itt is felmerülnek kétségek $(4,29)$. A privátszféra esetén jól látható, hogy egy hivatalosan dedikált szerkesztő által kínált tartalomban mind megbízhatóság, mind pedig hitelesség tekintetében jobban megbíztak a kitöltők, mint egy ismerős által szerkesztett tartalom esetén.

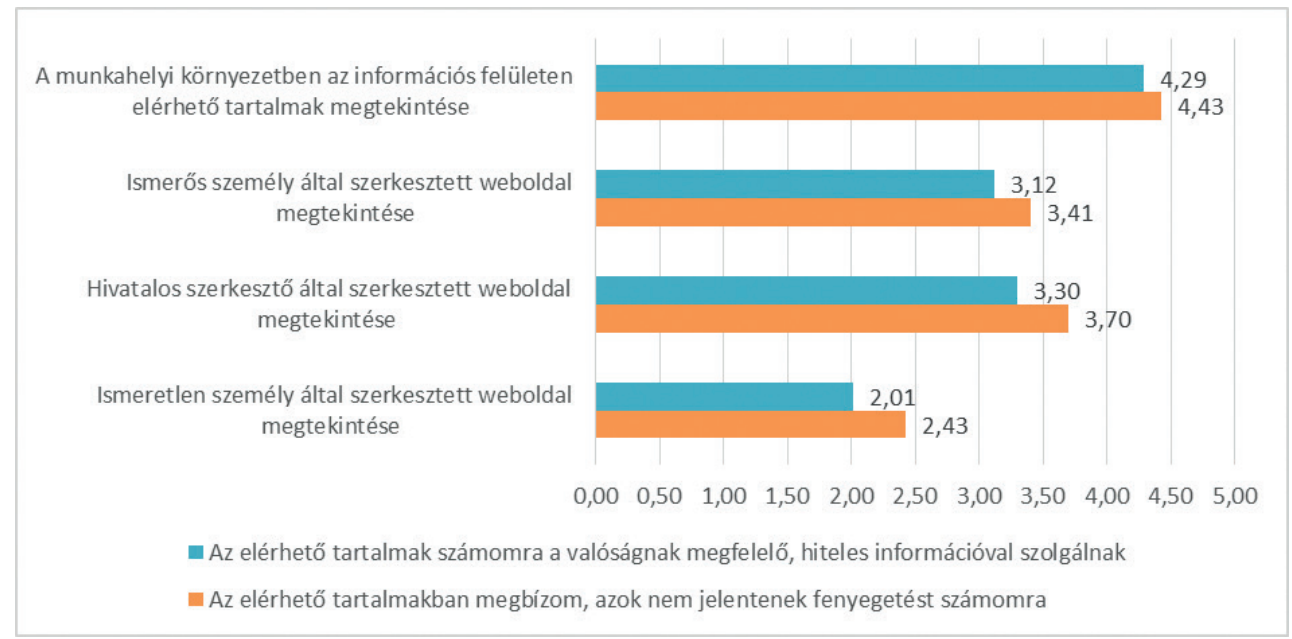

6. ábra: Az elérhetô tartalmak megbizhatóságának, illetve hitelességének megitélése átlagban a teljes minta átlaga szerint $(n=928)$. Forrás: a szerző szerkesztése 
Amennyiben az információ megbízhatóságát vizsgáljuk, úgy az egyes kérdésekre kapott válaszokban többnyire gyenge korrelációs kapcsolatot találunk. A legnagyobb korrelációs együttható az ismeretlen személy által szerkesztett weboldal és az ismerős által szerkesztett weboldal kérdéspárnál látszik $(r=0,416)$, illetve a hivatalos szerkesztő és az ismerős szerkesztő összevetésekor ( $r=0,397)$, de ezek is csak közepes korrelációs értékek. A hitelesség esetében sem találunk erős korrelációt, a legerősebb ebben az esetben a hivatalos szerkesztő által szerkesztett weboldal és az ismerős által szerkesztett weboldal $(r=0,393)$ párok. Ellenben ha megnézzük a megbízhatóság és a hitelesség összevetését, már sokkal nagyobb korrelációs értékeket találunk. A legerősebb korreláció $(r=0,628)$ a munkahelyi weboldalak tartalmi megbízhatósága és tartalmi hitelessége terén látható, de összességében még itt sem beszélhetünk erős korrelációról $(r>=|0,7|)$.

3. táblázat: Az elérhető tartalmak megbizhatóságának (első négy oszlop), illetve hitelességének (második négy oszlop) megítélése kérdéskörben kapott válaszok korrelációja

( $n$ = 928). Forrás: a szerző szerkesztése

\begin{tabular}{|c|c|c|c|c|c|c|c|c|c|}
\hline & & $\begin{array}{l}\text { Ismeretlen } \\
\text { személy } \\
\text { által szer- } \\
\text { kesztett } \\
\text { weboldal } \\
\text { megtekin- } \\
\text { tése }\end{array}$ & $\begin{array}{c}\text { Hivatalos } \\
\text { szerkesz- } \\
\text { tő által } \\
\text { szerkesz- } \\
\text { tett } \\
\text { weboldal } \\
\text { megtekin- } \\
\text { tése }\end{array}$ & $\begin{array}{c}\text { Ismerös } \\
\text { személy } \\
\text { által szer- } \\
\text { kesztett } \\
\text { weboldal } \\
\text { megtekin- } \\
\text { tése }\end{array}$ & $\begin{array}{l}\text { A munkahe- } \\
\text { lyi környe- } \\
\text { zetben az } \\
\text { információs } \\
\text { felületen } \\
\text { elérhetö } \\
\text { tartalmak } \\
\text { megtekin- } \\
\text { tése }\end{array}$ & $\begin{array}{c}\text { Ismeretlen } \\
\text { személy } \\
\text { által szer- } \\
\text { kesztett } \\
\text { weboldal }\end{array}$ & $\begin{array}{c}\text { Hivatalos } \\
\text { szerkesz- } \\
\text { tő́láltal } \\
\text { szerkesz- } \\
\text { tett web- } \\
\text { oldal }\end{array}$ & $\begin{array}{c}\text { Ismerős } \\
\text { személy } \\
\text { által szer- } \\
\text { kesztett } \\
\text { weboldal }\end{array}$ & $\begin{array}{l}\text { A munka- } \\
\text { helyi kör- } \\
\text { nyezetben } \\
\text { az infor- } \\
\text { mációs } \\
\text { felületen } \\
\text { elérhető } \\
\text { tartalmak }\end{array}$ \\
\hline $\begin{array}{c}\text { Ismeretlen } \\
\text { személy } \\
\text { által szer- } \\
\text { kesztett } \\
\text { weboldal } \\
\text { megtekin- } \\
\text { tése } \\
\end{array}$ & 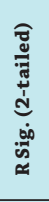 & 1,000 & $\begin{array}{c}0,228^{* *} \\
0,000\end{array}$ & $\begin{array}{c}0,416^{* *} \\
0,000\end{array}$ & $\begin{array}{c}-0,077^{*} \\
0,019\end{array}$ & $\begin{array}{c}0,524^{* *} \\
0,000\end{array}$ & $\begin{array}{l}0,049 \\
0,135\end{array}$ & $\begin{array}{c}0,201^{* *} \\
0,000\end{array}$ & $\begin{array}{c}-0,137^{* *} \\
0,000\end{array}$ \\
\hline $\begin{array}{c}\text { Hivatalos } \\
\text { szerkesztô } \\
\text { által szer- } \\
\text { kesztett } \\
\text { weboldal } \\
\text { megtekin- } \\
\text { tése } \\
\end{array}$ & 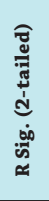 & $\begin{array}{c}0,228^{* *} \\
0,000\end{array}$ & 1,000 & $\begin{array}{c}0,397^{* *} \\
0,000\end{array}$ & $\begin{array}{c}0,315^{* *} \\
0,000\end{array}$ & $\begin{array}{l}0,050 \\
0,129\end{array}$ & $\begin{array}{c}0,517^{* *} \\
0,000\end{array}$ & $\begin{array}{c}0,274^{* *} \\
0,000\end{array}$ & $\begin{array}{c}0,247^{* *} \\
0,000\end{array}$ \\
\hline $\begin{array}{c}\text { Ismerös } \\
\text { személy } \\
\text { által szer- } \\
\text { kesztett } \\
\text { weboldal } \\
\text { megtekin- } \\
\text { tése }\end{array}$ & 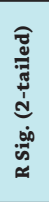 & $\begin{array}{c}0,416^{* *} \\
0,000\end{array}$ & $\begin{array}{c}0,397^{* *} \\
0,000\end{array}$ & 1,000 & $\begin{array}{c}0,232^{* *} \\
0,000\end{array}$ & $\begin{array}{c}0,215^{* *} \\
0,000\end{array}$ & $\begin{array}{c}0,198^{* *} \\
0,000\end{array}$ & $\begin{array}{c}0,518^{* *} \\
0,000\end{array}$ & $\begin{array}{c}0,628^{* *} \\
0,000\end{array}$ \\
\hline $\begin{array}{c}\text { A munkahe- } \\
\text { lyi környe- } \\
\text { zetben az } \\
\text { információs } \\
\text { felületen } \\
\text { elérhetö } \\
\text { tartalmak } \\
\text { megtekin- } \\
\text { tése }\end{array}$ & 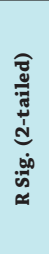 & $\begin{array}{c}-0,077^{*} \\
0,019\end{array}$ & $\begin{array}{c}0,315^{* *} \\
0,000\end{array}$ & $\begin{array}{c}0,232^{* *} \\
0,000\end{array}$ & 1,000 & $\begin{array}{c}-0,100^{* *} \\
0,002\end{array}$ & $\begin{array}{c}0,195^{* *} \\
0,000\end{array}$ & $\begin{array}{c}0,145^{* *} \\
0,000\end{array}$ & $\begin{array}{c}0,628^{* *} \\
0,000\end{array}$ \\
\hline
\end{tabular}




\begin{tabular}{|c|c|c|c|c|c|c|c|c|c|}
\hline & & $\begin{array}{c}\text { Ismeretlen } \\
\text { személy } \\
\text { által szer- } \\
\text { kesztett } \\
\text { weboldal } \\
\text { megtekin- } \\
\text { tése }\end{array}$ & \begin{tabular}{|c|} 
Hivatalos \\
szerkesz- \\
tó által \\
szerkesz- \\
tett \\
weboldal \\
megtekin- \\
tése
\end{tabular} & $\begin{array}{c}\text { Ismerôs } \\
\text { személy } \\
\text { által szer- } \\
\text { kesztett } \\
\text { weboldal } \\
\text { megtekin- } \\
\text { tése }\end{array}$ & \begin{tabular}{|c|} 
A munkahe- \\
lyi környe- \\
zetben az \\
információs \\
felületen \\
elérhetö \\
tartalmak \\
megtekin- \\
tése \\
\end{tabular} & $\begin{array}{c}\text { Ismeretlen } \\
\text { személy } \\
\text { által szer- } \\
\text { kesztett } \\
\text { weboldal }\end{array}$ & $\begin{array}{c}\text { Hivatalos } \\
\text { szerkesz- } \\
\text { tő által } \\
\text { szerkesz- } \\
\text { tett web- } \\
\text { oldal }\end{array}$ & \begin{tabular}{|c|} 
Ismerôs \\
személy \\
által szer- \\
kesztett \\
weboldal
\end{tabular} & $\begin{array}{c}\text { A munka- } \\
\text { helyi kör- } \\
\text { nyezetben } \\
\text { az infor- } \\
\text { mációs } \\
\text { felületen } \\
\text { elérhetô } \\
\text { tartalmak }\end{array}$ \\
\hline $\begin{array}{c}\text { Ismeretlen } \\
\text { személy } \\
\text { által szer- } \\
\text { kesztett } \\
\text { weboldal }\end{array}$ & 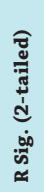 & $\begin{array}{c}0,524^{* *} \\
, 000\end{array}$ & $\begin{array}{l}0,050 \\
0,129\end{array}$ & $\begin{array}{c}0,215^{* *} \\
0,000\end{array}$ & $\begin{array}{c}-0,100^{* *} \\
0,002\end{array}$ & 1,000 & $\begin{array}{c}0,216^{* *} \\
0,000\end{array}$ & $\begin{array}{c}0,309^{* *} \\
0,000\end{array}$ & $\begin{array}{c}-0,133^{* *} \\
0,000\end{array}$ \\
\hline $\begin{array}{c}\text { Hivatalos } \\
\text { szerkesztô } \\
\text { által szer- } \\
\text { kesztett } \\
\text { weboldal }\end{array}$ & 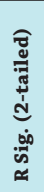 & $\begin{array}{l}0,049 \\
0,135\end{array}$ & $\begin{array}{c}0,517^{* *} \\
0,000\end{array}$ & $\begin{array}{c}0,198^{* *} \\
0,000\end{array}$ & $\begin{array}{c}0,195^{* *} \\
0,000\end{array}$ & $\begin{array}{c}0,216^{* *} \\
0,000\end{array}$ & 1,000 & $\begin{array}{c}0,393^{* *} \\
0,000\end{array}$ & $\begin{array}{c}0,310^{* *} \\
0,000\end{array}$ \\
\hline $\begin{array}{c}\text { Ismerös } \\
\text { személy } \\
\text { által szer- } \\
\text { kesztett } \\
\text { weboldal }\end{array}$ & 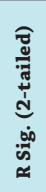 & $\begin{array}{c}0,201^{* *} \\
0,000\end{array}$ & $\begin{array}{c}0,274^{* *} \\
0,000\end{array}$ & $\begin{array}{c}0,518^{* *} \\
0,000\end{array}$ & $\begin{array}{c}0,145^{* *} \\
0,000\end{array}$ & $\begin{array}{c}0,309^{* *} \\
0,000\end{array}$ & $\begin{array}{c}0,393^{* *} \\
0,000\end{array}$ & 1,000 & $\begin{array}{c}0,269^{* *} \\
0,000\end{array}$ \\
\hline $\begin{array}{l}\text { A munkahe- } \\
\text { lyi környe- } \\
\text { zetben az } \\
\text { információs } \\
\text { felületen } \\
\text { elérhető } \\
\text { tartalmak }\end{array}$ & 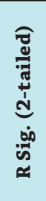 & $\begin{array}{c}-0,137^{* *} \\
0,000\end{array}$ & $\begin{array}{c}0,247^{* *} \\
0,000\end{array}$ & $\begin{array}{c}0,133^{* *} \\
0,000\end{array}$ & $\begin{array}{c}0,628^{* *} \\
0,000\end{array}$ & $\begin{array}{c}-0,133^{* *} \\
0,000\end{array}$ & $\begin{array}{c}0,310^{* *} \\
0,000\end{array}$ & $\begin{array}{c}0,269^{* *} \\
0,000\end{array}$ & 1,000 \\
\hline
\end{tabular}

Az adatok összevetése a vezetői és a beosztotti minta esetén azt mutatja, hogy a válaszadás független volt a beosztástól. Ugyanakkor az iskolai végzettség esetén már eltérés tapasztalható a mintában a hivatalos szerkesztő (M-W: 64725,5 p =0,003), illetve az ismerős által szerkesztett weboldalak (M-W: 67177,5 p =0,034) megbízhatósága esetén. 
4. táblázat: Az elérhetô tartalmak megbízhatóságának (első négy oszlop), illetve hitelességének (második négy oszlop) megítélése kérdéskörbe tartozó minták különbözőségének vizsgálata a beosztás, illetve az informatikai végzettség megléte tükrében

( $n=928 ; p=0,05)$. Forrás: a szerző szerkesztése

\begin{tabular}{|c|c|c|c|c|c|c|c|c|c|}
\hline & & $\begin{array}{c}\text { Ismeretlen } \\
\text { személy } \\
\text { által szer- } \\
\text { kesztett } \\
\text { weboldal } \\
\text { megtekin- } \\
\text { tése } \\
\end{array}$ & $\begin{array}{c}\text { Hivatalos } \\
\text { szerkesztő } \\
\text { által szer- } \\
\text { kesztett } \\
\text { weboldal } \\
\text { megtekin- } \\
\text { tése } \\
\end{array}$ & $\begin{array}{c}\text { Ismerös } \\
\text { személy } \\
\text { által szer- } \\
\text { kesztett } \\
\text { weboldal } \\
\text { megtekin- } \\
\text { tése } \\
\end{array}$ & $\begin{array}{c}\text { A munkahelyi } \\
\text { környezetben } \\
\text { az informá- } \\
\text { ciós felületen } \\
\text { elérhető tar- } \\
\text { talmak meg- } \\
\text { tekintése } \\
\end{array}$ & \begin{tabular}{|c|} 
Isme- \\
retlen \\
személy \\
által szer- \\
kesztett \\
weboldal
\end{tabular} & \begin{tabular}{|c|} 
Hivatalos \\
szerkesz- \\
tő által \\
szerkesz- \\
tett web- \\
oldal
\end{tabular} & $\begin{array}{c}\text { Ismerôs } \\
\text { személy } \\
\text { által szer- } \\
\text { kesztett } \\
\text { weboldal }\end{array}$ & $\begin{array}{l}\text { A munkahelyi } \\
\text { környezetben } \\
\text { az informá- } \\
\text { ciós felületen } \\
\text { elérhetoó tar- } \\
\text { talmak }\end{array}$ \\
\hline A & 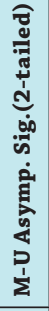 & $\begin{array}{r}63163,000 \\
0,978\end{array}$ & $\begin{array}{r}60097,000 \\
0,270\end{array}$ & $\begin{array}{r}61384,000 \\
0,523\end{array}$ & $\begin{array}{r}61982,500 \\
0,648\end{array}$ & $\begin{array}{r}63027,000 \\
0,941\end{array}$ & $\begin{array}{r}61455,500 \\
0,544\end{array}$ & $\begin{array}{r}60890,500 \\
0,423\end{array}$ & $\begin{array}{r}63209,500 \\
0,990\end{array}$ \\
\hline B & 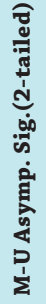 & $\begin{array}{r}72066,000 \\
0,583\end{array}$ & $\begin{array}{r}64725,500 \\
0,003\end{array}$ & $\begin{array}{r}67177,500 \\
0,034\end{array}$ & $\begin{array}{r}73355,500 \\
0,869\end{array}$ & $\begin{array}{r}67753,500 \\
0,057\end{array}$ & $\begin{array}{r}71676,500 \\
0,496\end{array}$ & $\begin{array}{r}70924,500 \\
0,357\end{array}$ & $\begin{array}{r}71452,000 \\
0,435\end{array}$ \\
\hline
\end{tabular}

Amennyiben a generációk szerint vizsgáljuk a mintákat, láthatóvá válik, hogy majdnem az összes kérdés esetén a kapott minták eltérők. A megbízhatóság kérdéskörében a hivatalos szerkesztővel rendelkező $\left(\chi^{2}=5,516 ; p=0,138\right)$, illetve a hivatali környezetben lévő információforrásokról vélekednek hasonlóan $\left(\chi^{2}=4,033 ; \mathrm{p}=0,258\right)$ a kitöltők generációtól függetlenül. A Hivatal számára fontos visszajelzés, hogy a hitelesség megítélésére kapott válaszok generációs mintájának összevetésekor ugyan nem jelenthető ki egyértelműen a szignifikáns különbség, de a kapott értékek alapján $\left(\chi^{2}=7,649 ; \mathrm{p}=0,054\right)$ a generációk mintája jelentősen eltérő, további vizsgálatot igényel. 
5. táblázat: Az elérhetô tartalmak megbízhatóságának (első négy oszlop), illetve hitelességének (második négy oszlop) megitélése kérdéskörbe tartozó minták különbözőségének vizsgálata a generációk tükrében $(n=928 ; p=0,05)$. Forrás: a szerzô szerkesztése

\begin{tabular}{|c|c|c|c|c|c|c|c|c|}
\hline \multicolumn{9}{|c|}{ Test Statistics } \\
\hline & $\begin{array}{c}\text { Isme- } \\
\text { retlen } \\
\text { személy } \\
\text { által } \\
\text { szer- } \\
\text { kesz- } \\
\text { tett } \\
\text { web- } \\
\text { oldal } \\
\text { megte- } \\
\text { kintése }\end{array}$ & $\begin{array}{c}\text { Hivatalos } \\
\text { szerkesz- } \\
\text { tő által } \\
\text { szerkesz- } \\
\text { tett } \\
\text { weboldal } \\
\text { megte- } \\
\text { kintése }\end{array}$ & $\begin{array}{c}\text { Ismeröss } \\
\text { személy } \\
\text { által } \\
\text { szer- } \\
\text { kesz- } \\
\text { tett } \\
\text { web- } \\
\text { oldal } \\
\text { megte- } \\
\text { kintése }\end{array}$ & $\begin{array}{c}\text { A mun- } \\
\text { kahelyi } \\
\text { környe- } \\
\text { zetben } \\
\text { az infor- } \\
\text { mációs } \\
\text { felületen } \\
\text { elérhetö } \\
\text { tartalmak } \\
\text { megtekin- } \\
\text { tése }\end{array}$ & $\begin{array}{c}\text { Isme- } \\
\text { retlen } \\
\text { személy } \\
\text { által } \\
\text { szer- } \\
\text { kesztett } \\
\text { weboldal }\end{array}$ & $\begin{array}{l}\text { Hivatalos } \\
\text { szerkesz- } \\
\text { tő által } \\
\text { szerkesz- } \\
\text { tett web- } \\
\text { oldal }\end{array}$ & $\begin{array}{c}\text { Ismerős } \\
\text { személy } \\
\text { által szer- } \\
\text { kesztett } \\
\text { weboldal }\end{array}$ & $\begin{array}{c}\text { A mun- } \\
\text { kahelyi } \\
\text { környe- } \\
\text { zetben } \\
\text { az infor- } \\
\text { mációs } \\
\text { felületen } \\
\text { elérhetö } \\
\text { tartal- } \\
\text { mak }\end{array}$ \\
\hline $\begin{array}{l}\text { Chi- } \\
\text { Square } \\
\text { df } \\
\text { Asymp. } \\
\text { Sig. }\end{array}$ & $\begin{array}{r}16,945 \\
3,001\end{array}$ & $\begin{array}{l}5,516 \\
3,138\end{array}$ & $\begin{array}{r}11,733 \\
3,008\end{array}$ & $\begin{array}{l}4,033 \\
3,258\end{array}$ & $\begin{array}{r}20,891 \\
3,000\end{array}$ & $\begin{array}{l}4,432 \\
3,218\end{array}$ & $\begin{array}{l}5,937 \\
3,115\end{array}$ & $\begin{array}{l}7,649 \\
3,054\end{array}$ \\
\hline $\begin{array}{l}\text { a. Krus } \\
\text { b. Grou }\end{array}$ & $\begin{array}{l}\text { s Test } \\
\text { iable: } G\end{array}$ & & & & & & & \\
\hline
\end{tabular}

\section{A kapott tartalmak megbízhatóságának, illetve hitelességének megítélése}

Kapott információ esetén az információ nem önszerveződés útján kerül a birtokunkba, hanem valamely más személy által vagy annak megbízásából. Alapvetően két csatorna került a vizsgálat célpontjába, az aszinkron kommunikációt ${ }^{11}$ biztosító elektronikus levelezés, illetve a szinkron kommunikációt ${ }^{12}$ lehetôvé tevő üzenetküldő szolgáltatások.

A válaszok átlagértéke alapján az látszik, hogy a privátszférában sokkal kevésbé bízunk meg a kapott tartalmakban, mint a munkahelyi környezetben. Ugyanakkor érdemes megfigyelni, hogy bár a kitöltők nagy része úgy véli, az ismeretlenektől kapott információ fenyegetést rejthet (1,48 és 1,62), de a tartalom hitelességében ehhez képest mégis jelentősebb mértékben hisznek (2,28 és 2,47$)$.

11 Az információáramlás a kommunikációban szereplő személyek között nem valós időben történik, a személyek nem egy időben vesznek részt a tevékenységben.

12 Az információáramlás a kommunikációban szereplő személyek között valós időben történik, a személyek egyidejúleg részt vesznek a tevékenységben. 
A munkahelyi környezetben kapott tartalmak megbízhatóságát (függetlenül a küldő személyétől) sem ítélték meg a kitöltők magasan. A közvetlen vezetőtől $(4,18)$ és a felsővezetőtől $(4,16)$ e-mail útján érkező tartalomban bíznak meg leginkább, de ezek átlaga is éppen csak átlépi a 4-es szintet. A kapott tartalom hitelességének a megítélése még rosszabb, itt már csak a felsővezetőtől e-mail útján érkező információ hitelességében $(4,07)$ bíztak meg leginkább a válaszadók. Az átlagok vizsgálata során az is észrevehető, hogy az azonnali üzenetváltást lehetővé tevő eszközökön keresztül érkező tartalmakkal szemben nagyobb a bizalmatlanság, mint az e-mail útján érkezett tartalmak esetében.

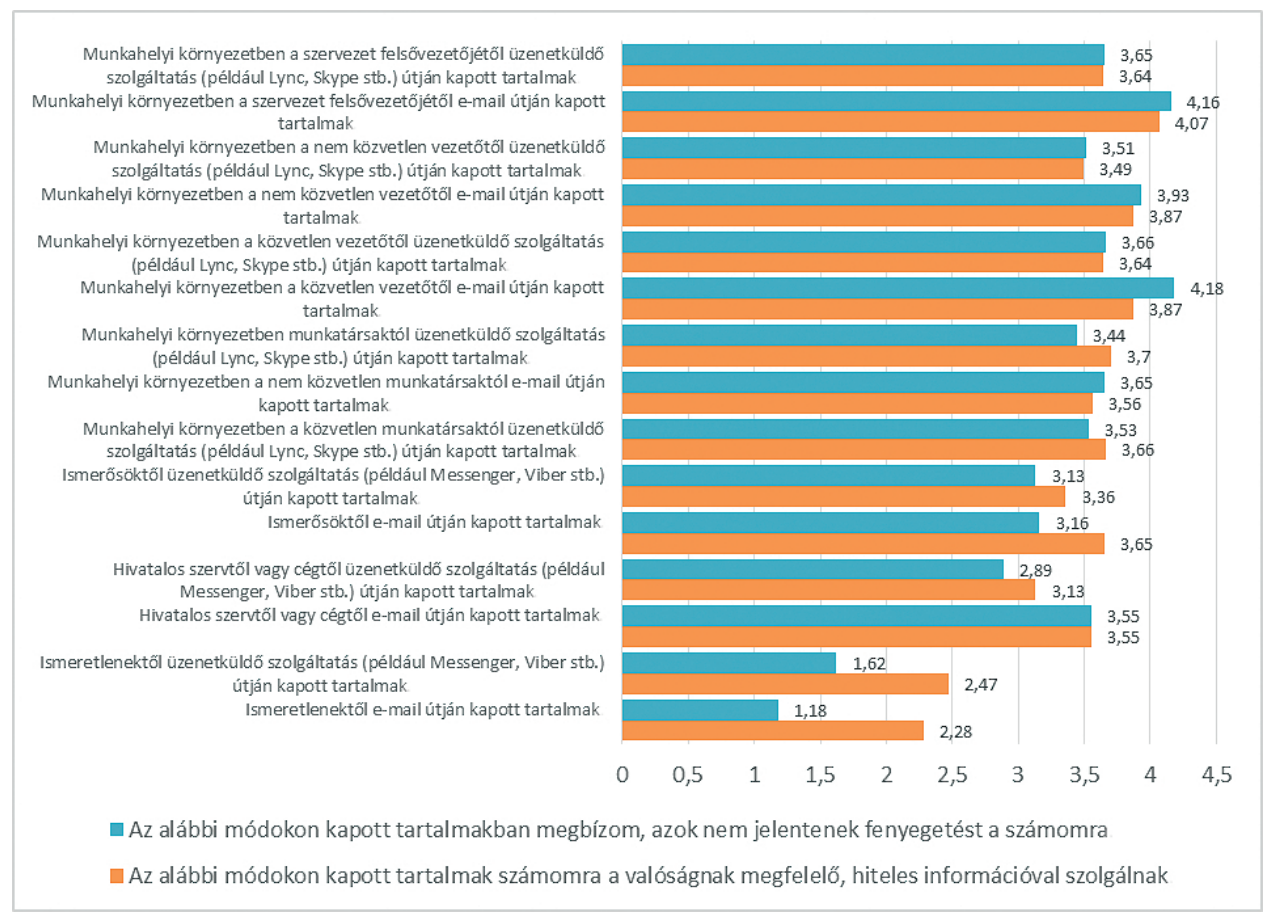

7. ábra: A kapott tartalmak megbízhatóságának, illetve hitelességének megitélése átlagban a teljes minta átlaga szerint $(n=928)$. Forrás: a szerző szerkesztése

A megbízhatóság és a hitelesség körében kapott válaszok korrelációvizsgálata során már számos erôs korrelációt tapasztalhatunk, különösen a munkahelyi környezetet érintő kérdésekben. Ezeknél többnyire erős korreláció $(r>=|0,7|)$ látható akkor, ha a kapott tartalom azonos csatornán (e-mail vagy üzenetküldő) érkezik, függetlenül a feladó személyétől. 


\section{6. táblázat: A kapott tartalmak megbizhatóságának megitélése kérdéskörben kapott válaszok korrelációja (n=928). Forrás: a szerző szerkesztése}

\begin{tabular}{|c|c|c|c|c|c|c|c|c|c|c|c|c|c|c|c|c|c|}
\hline & & 1. & 2. & 3. & 4. & 5. & 6. & 7. & 8. & 9. & 10. & 11. & 12. & 13. & 14. & 15. & 16. \\
\hline 1. & \multirow{10}{*}{ 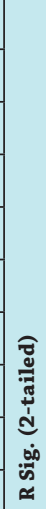 } & 000 & $\begin{array}{c}0,730^{* *} \\
0,000\end{array}$ & $\begin{array}{c}0,068^{*} \\
0,040\end{array}$ & $\begin{array}{c}0,175^{* *} \\
0,000\end{array}$ & $\begin{array}{c}0,192^{* *} \\
0,000\end{array}$ & $\begin{array}{c}0,203^{* *} \\
0,000\end{array}$ & $\begin{array}{c}-0,040 \\
0,226\end{array}$ & $\begin{array}{l}0,060 \\
0,066\end{array}$ & $\begin{array}{l}0,034 \\
0,307\end{array}$ & $\begin{array}{c}0,082^{*} \\
0,012\end{array}$ & $\begin{array}{r}-0,067^{\circ} \\
0,043\end{array}$ & $\begin{array}{l}0,058 \\
0,077\end{array}$ & $\begin{array}{c}-0,028 \\
0,391\end{array}$ & $\begin{array}{r}0,066^{\circ} \\
0,044\end{array}$ & $\begin{array}{l}-0,063 \\
0,055\end{array}$ & $\begin{array}{l}074^{\circ} \\
0,024\end{array}$ \\
\hline 2. & & $\begin{array}{c}0,730^{* *} \\
0,000\end{array}$ & 1,000 & $\begin{array}{r}0,069^{*} \\
0,036\end{array}$ & $\begin{array}{c}0,224^{* *} \\
0,000\end{array}$ & $\begin{array}{c}0,181^{* *} \\
0,000\end{array}$ & $\begin{array}{l}231^{* *} \\
, 000\end{array}$ & $\begin{array}{c}-0,023 \\
0,483\end{array}$ & $\begin{array}{r}0,082^{*} \\
0,012\end{array}$ & $\begin{array}{l}039 \\
240\end{array}$ & $\begin{array}{l}0,102^{* *} \\
0,002\end{array}$ & & $\begin{array}{l}, 061 \\
, 064\end{array}$ & & $\begin{array}{r}0,080^{*} \\
0,015\end{array}$ & $\begin{array}{l}052 \\
112\end{array}$ & $\begin{array}{l}0,089^{* *} \\
0,007\end{array}$ \\
\hline 3. & & $\begin{array}{c}0,068^{*} \\
0,040\end{array}$ & $\begin{array}{c}0,069^{*} \\
0,036\end{array}$ & 1,000 & $\begin{array}{c}0,479^{* *} \\
0,000\end{array}$ & $\begin{array}{c}0,293^{* *} \\
0,000\end{array}$ & $\begin{array}{c}0,246^{* *} \\
0,000\end{array}$ & $\begin{array}{c}0,316^{*} \\
0,000\end{array}$ & $\begin{array}{c}0,249^{* *} \\
0,000\end{array}$ & $\begin{array}{c}0,264^{* *} \\
0,000\end{array}$ & & $\begin{array}{c}0,348^{* *} \\
0,000\end{array}$ & $\begin{array}{c}0,242^{* *} \\
0,000\end{array}$ & & & & $\begin{array}{c}0,250^{* *} \\
0,000\end{array}$ \\
\hline 4. & & $\begin{array}{c}0,175^{* *} \\
0,000\end{array}$ & $\begin{array}{c}0,224^{* *} \\
0,000\end{array}$ & $\begin{array}{c}0,479^{* *} \\
0,000\end{array}$ & 1,000 & 0,000 & $\begin{array}{c}0,293^{* *} \\
0,000\end{array}$ & $\begin{array}{c}0,188^{* *} \\
0,000\end{array}$ & $\begin{array}{c}0,298^{* *} \\
0,000\end{array}$ & $\begin{array}{c}0,225^{* *} \\
0,000\end{array}$ & $\begin{array}{c}0,321^{* *} \\
0,000\end{array}$ & $\begin{array}{c}0,156^{* *} \\
0,000\end{array}$ & $\begin{array}{c}0,285^{* *} \\
0,000\end{array}$ & & & & $\begin{array}{c}0,340^{* *} \\
0,000\end{array}$ \\
\hline 5. & & $\begin{array}{c}0,192^{* *} \\
0,000\end{array}$ & $\begin{array}{c}0,181^{* *} \\
0,000\end{array}$ & $\begin{array}{c}0,293^{* *} \\
0,000\end{array}$ & 0,000 & 1,000 & $\begin{array}{c}0,788^{* *} \\
0,000\end{array}$ & $\begin{array}{c}0,359^{* *} \\
0,000\end{array}$ & $\begin{array}{c}0,307^{* *} \\
0,000\end{array}$ & & & & & & & & $\begin{array}{c}0,245^{* *} \\
0,000\end{array}$ \\
\hline 6. & & $\begin{array}{c}0,203^{* *} \\
0,000\end{array}$ & $\begin{array}{c}0,231^{* *} \\
0,000\end{array}$ & $\begin{array}{c}0,246^{* *} \\
0,000\end{array}$ & $\begin{array}{c}0,293^{* *} \\
0,000\end{array}$ & $\begin{array}{c}0,00 \\
0,000\end{array}$ & 1,000 & $\begin{array}{c}0,367^{* *} \\
0,000\end{array}$ & $\begin{array}{c}0,355^{* *} \\
0,000\end{array}$ & & & & & & & & $\begin{array}{c}0,307^{* *} \\
0,000\end{array}$ \\
\hline 7. & & $\begin{array}{c}-0,040 \\
0,226\end{array}$ & $\begin{array}{c}-0,023 \\
0,483\end{array}$ & $\begin{array}{c}0,316^{* *} \\
0,000\end{array}$ & $\begin{array}{c}0,188^{* *} \\
0,000\end{array}$ & $\begin{array}{c}0,359^{* *} \\
0,000\end{array}$ & $\begin{array}{c}0,367^{* *} \\
0,000\end{array}$ & 1,000 & $\begin{array}{c}0,547^{* *} \\
0,000\end{array}$ & $\begin{array}{c}0,693^{* *} \\
0,000\end{array}$ & $\begin{array}{c}0,489^{* *} \\
0,000\end{array}$ & $\begin{array}{c}0,783^{* *} \\
0,000\end{array}$ & $\begin{array}{c}0,475^{* *} \\
0,000\end{array}$ & $\begin{array}{c}0,725^{* *} \\
0,000\end{array}$ & $\begin{array}{c}0,466^{* *} \\
0,000\end{array}$ & $\begin{array}{c}0,697^{* *} \\
0,000\end{array}$ & $\begin{array}{c}0,412^{* *} \\
0,000\end{array}$ \\
\hline 8. & & $\begin{array}{l}0,060 \\
0,066\end{array}$ & $\begin{array}{c}0,082^{*} \\
0,012\end{array}$ & $\begin{array}{c}0,249^{* *} \\
0,000\end{array}$ & $\begin{array}{c}0,298^{* *} \\
0,000\end{array}$ & $\begin{array}{c}0,307^{* *} \\
0,000\end{array}$ & $\begin{array}{c}0,355^{* *} \\
0,000\end{array}$ & $\begin{array}{c}0,547^{* *} \\
0,000\end{array}$ & 1,000 & $\begin{array}{c}0,541^{* *} \\
0,000\end{array}$ & $\begin{array}{c}0,840^{* *} \\
0,000\end{array}$ & $\begin{array}{c}0,484^{* *} \\
0,000\end{array}$ & $\begin{array}{c}0,835^{* *} \\
0,000\end{array}$ & $\begin{array}{c}0,496^{* *} \\
0,000\end{array}$ & $\begin{array}{c}0,823^{* *} \\
0,000\end{array}$ & $\begin{array}{l}0,450^{\circ *} \\
0,000\end{array}$ & $\begin{array}{c}0,798^{* *} \\
0,000\end{array}$ \\
\hline 9 & & $\begin{array}{l}0,034 \\
0,307\end{array}$ & $\begin{array}{l}0,039 \\
0,240\end{array}$ & $\begin{array}{c}0,264^{* *} \\
0,000\end{array}$ & $\begin{array}{c}0,225^{* *} \\
0,000\end{array}$ & $\begin{array}{c}0,294^{* *} \\
0,000\end{array}$ & $\begin{array}{c}0,318^{* *} \\
0,000\end{array}$ & $\begin{array}{c}0,693^{* *} \\
0,000\end{array}$ & $\begin{array}{c}0,541^{* *} \\
0,000\end{array}$ & 1,000 & $\begin{array}{c}0,604^{* *} \\
0,000\end{array}$ & $\begin{array}{c}0,609^{* *} \\
0,000\end{array}$ & $\begin{array}{c}0,484^{* *} \\
0,000\end{array}$ & & & & $\begin{array}{c}0,427^{* *} \\
0,000\end{array}$ \\
\hline 10. & & $\begin{array}{r}0,082^{*} \\
0,012\end{array}$ & $\begin{array}{c}0,102^{* *} \\
0,002\end{array}$ & $\begin{array}{c}0,251^{* *} \\
0,000\end{array}$ & $\begin{array}{c}0,321^{* *} \\
0,000\end{array}$ & $\begin{array}{c}0,277^{* *} \\
0,000\end{array}$ & $\begin{array}{c}0,345^{* *} \\
0,000\end{array}$ & $\begin{array}{c}0,489^{* *} \\
0,000\end{array}$ & $\begin{array}{c}0,840^{* *} \\
0,000\end{array}$ & $\begin{array}{c}0,604^{* *} \\
0,000\end{array}$ & 1,000 & $\begin{array}{c}0,466^{* *} \\
0,000\end{array}$ & $\begin{array}{c}0,826^{* *} \\
0,000\end{array}$ & $\begin{array}{c}0,504^{* *} \\
0,000\end{array}$ & $\begin{array}{c}0,831^{* *} \\
0,000\end{array}$ & $\begin{array}{c}0,438^{* *} \\
0,000\end{array}$ & $\begin{array}{c}0,791^{* *} \\
0,000\end{array}$ \\
\hline 11. & & $\begin{array}{c}-0,067^{*} \\
0,043\end{array}$ & $\begin{array}{c}-0,071^{*} \\
0,030\end{array}$ & $\begin{array}{c}0,348^{* *} \\
0,000\end{array}$ & $\begin{array}{c}0,156^{* *} \\
0,000\end{array}$ & $\begin{array}{c}0,324^{* *} \\
0,000\end{array}$ & $\begin{array}{c}0,320^{* *} \\
0,000\end{array}$ & $\begin{array}{c}0,783^{* *} \\
0,000\end{array}$ & $\begin{array}{c}0,484^{* *} \\
0,000\end{array}$ & $\begin{array}{c}0,609^{* *} \\
0,000\end{array}$ & $\begin{array}{c}0,466^{* *} \\
0,000\end{array}$ & 1 & $\begin{array}{c}0,565^{* *} \\
0,000\end{array}$ & $\begin{array}{c}0,782^{* *} \\
0,000\end{array}$ & $\begin{array}{c}0,492^{* *} \\
0,000\end{array}$ & $\begin{array}{c}0,874^{* *} \\
0,000\end{array}$ & $\begin{array}{c}0,496^{* *} \\
0,000\end{array}$ \\
\hline 12. & & $\begin{array}{l}0,058 \\
0,077\end{array}$ & $\begin{array}{l}0,061 \\
0,064\end{array}$ & $\begin{array}{c}0,242^{* *} \\
0,000\end{array}$ & $\begin{array}{c}0,285^{* *} \\
0,000\end{array}$ & $\begin{array}{c}0,290^{* *} \\
0,000\end{array}$ & $\begin{array}{c}0,344^{* *} \\
0,000\end{array}$ & $\begin{array}{c}0,475^{* *} \\
0,000\end{array}$ & $\begin{array}{c}0,835^{* *} \\
0,000\end{array}$ & $\begin{array}{c}0,484^{* *} \\
0,000\end{array}$ & $\begin{array}{c}0,826^{* *} \\
0,000\end{array}$ & $\begin{array}{c}0,565^{* *} \\
0,000\end{array}$ & 1,0 & $\begin{array}{c}0,503^{* *} \\
0,000\end{array}$ & $\begin{array}{c}0,878^{* *} \\
0,000\end{array}$ & $\begin{array}{c}0,527^{* *} \\
0,000\end{array}$ & $\begin{array}{c}0,884^{* *} \\
0,000\end{array}$ \\
\hline 13. & & $\begin{array}{c}-0,028 \\
0,391\end{array}$ & $\begin{array}{c}-0,030 \\
0,369\end{array}$ & $\begin{array}{c}0,308^{* *} \\
0,000\end{array}$ & $\begin{array}{c}0,182^{* *} \\
0,000\end{array}$ & $\begin{array}{c}0,298^{* *} \\
0,000\end{array}$ & $\begin{array}{c}0,319^{* *} \\
0,000\end{array}$ & $\begin{array}{c}0,725^{* *} \\
0,000\end{array}$ & $\begin{array}{c}0,496^{* *} \\
0,000\end{array}$ & $\begin{array}{c}0,742^{* *} \\
0,000\end{array}$ & $\begin{array}{c}0,504^{* *} \\
0,000\end{array}$ & $\begin{array}{c}0,782^{* *} \\
0,000\end{array}$ & $\begin{array}{c}0,503^{* *} \\
0,000\end{array}$ & 0 & $\begin{array}{c}0,616^{* *} \\
0,000\end{array}$ & $\begin{array}{c}0,738^{* *} \\
0,000\end{array}$ & $\begin{array}{c}0,448^{* *} \\
0,000\end{array}$ \\
\hline 14. & & $\begin{array}{r}0,066^{\circ} \\
0,044\end{array}$ & $\begin{array}{r}0,080^{*} \\
0,015\end{array}$ & $\begin{array}{c}0,238^{* *} \\
0,000\end{array}$ & $\begin{array}{c}0,314^{* *} \\
0,000\end{array}$ & $\begin{array}{c}0,259^{* *} \\
0,000\end{array}$ & $\begin{array}{c}0,318^{* *} \\
0,000\end{array}$ & $\begin{array}{c}0,466^{*} \\
0,000\end{array}$ & $\begin{array}{c}0,823^{* *} \\
0,000\end{array}$ & $\begin{array}{c}0,552^{* *} \\
0,000\end{array}$ & $\begin{array}{c}0,831^{* *} \\
0,000\end{array}$ & $\begin{array}{c}0,492^{*} \\
0,000\end{array}$ & $\begin{array}{c}0,878^{* *} \\
0,000\end{array}$ & $\begin{array}{c}0,616^{*} \\
0,000\end{array}$ & 1,000 & $\begin{array}{c}0,468^{* *} \\
0,000\end{array}$ & $\begin{array}{c}0,854^{* *} \\
0,000\end{array}$ \\
\hline 15. & & $\begin{array}{c}-0,063 \\
0,055\end{array}$ & $\begin{array}{c}-0,052 \\
0,112\end{array}$ & $\begin{array}{c}0,338^{* *} \\
0,000\end{array}$ & $\begin{array}{c}0,189^{* *} \\
0,000\end{array}$ & $\begin{array}{c}0,295^{* *} \\
0,000\end{array}$ & $\begin{array}{c}0,310^{* *} \\
0,000\end{array}$ & $\begin{array}{c}0,697^{* *} \\
0,000\end{array}$ & $\begin{array}{c}0,450^{* *} \\
0,000\end{array}$ & $\begin{array}{c}0,573^{* *} \\
0,000\end{array}$ & $\begin{array}{c}0,438^{* *} \\
0,000\end{array}$ & $\begin{array}{c}0,874^{* *} \\
0,000\end{array}$ & $\begin{array}{c}0,527^{* *} \\
0,000\end{array}$ & $\begin{array}{c}0,738^{* *} \\
0,000\end{array}$ & $\begin{array}{c}0,468^{* *} \\
0,000\end{array}$ & 1,000 & $\begin{array}{c}0,558^{* *} \\
0,000\end{array}$ \\
\hline 16. & & $\begin{array}{r}0,074^{\circ} \\
0,024\end{array}$ & $\begin{array}{c}0,089^{* *} \\
0,007\end{array}$ & $\begin{array}{c}0,250^{* *} \\
0,000\end{array}$ & $\begin{array}{c}0,340^{* *} \\
0,000\end{array}$ & $\begin{array}{c}0,245^{* *} \\
0,000\end{array}$ & $\begin{array}{c}0,307^{* *} \\
0,000\end{array}$ & $\begin{array}{c}0,412^{* *} \\
0,000\end{array}$ & $\begin{array}{c}0,798^{* *} \\
0,000\end{array}$ & $\begin{array}{c}0,427^{* *} \\
0,000\end{array}$ & $\begin{array}{c}0,791^{* *} \\
0,000\end{array}$ & $\begin{array}{c}0,496^{* *} \\
0,000\end{array}$ & $\begin{array}{c}0,884^{* *} \\
0,000\end{array}$ & $\begin{array}{c}0,448^{* *} \\
0,000\end{array}$ & $\begin{array}{c}0,854^{* *} \\
0,000\end{array}$ & $\begin{array}{c}0,558^{* *} \\
0,000\end{array}$ & 1,000 \\
\hline
\end{tabular}

** A korreláció szignifikáns a 0,01 szinten (2-tailed).

* A korreláció szignifikáns a 0,05 szinten (2-tailed).

1. Ismeretlenektöl e-mail útján kapott tartalmak

2. Ismeretlenektől üzenetküldő szolgáltatás (például Messenger, Viber stb.) útján kapott tartalmak

3. Hivatalos szervtől vagy cégtől e-mail útján kapott tartalmak

4. Hivatalos szervtől vagy cégtől üzenetküldő szolgáltatás (például Messenger, Viber stb.) útján kapott tartalmak

5. Ismerősöktöl e-mail útján kapott tartalmak

6. Ismerősöktől üzenetküldő szolgáltatás (például Messenger, Viber stb.) útján kapott tartalmak

7. Munkahelyi környezetben a közvetlen munkatársaktól e-mail útján kapott tartalmak

8. Munkahelyi környezetben a közvetlen munkatársaktól üzenetküldő szolgáltatás (például Lync, Skype stb.) útján kapott tartalmak

9. Munkahelyi környezetben a nem közvetlen munkatársaktól e-mail útján kapott tartalmak

10. Munkahelyi környezetben munkatársaktól üzenetküldő szolgáltatás (például Lync, Skype stb.) útján kapott tartalmak

11. Munkahelyi környezetben a közvetlen vezetőtől e-mail útján kapott tartalmak

12. Munkahelyi környezetben a közvetlen vezetötől üzenetküldő szolgáltatás (például Lync, Skype stb.) útján kapott tartalmak

13. Munkahelyi környezetben a nem közvetlen vezetőtől e-mail útján kapott tartalmak

14. Munkahelyi környezetben a nem közvetlen vezetőtöl üzenetküldő szolgáltatás (például Lync, Skype stb.) útján kapott tartalmak

15. Munkahelyi környezetben a szervezet felsővezetőjétöl e-mail útján kapott tartalmak

16. Munkahelyi környezetben a szervezet felsővezetőjétől üzenetküldő szolgáltatás (például Lync, Skype stb.) útján kapott tartalmak 


\section{7. táblázat: A kapott tartalmak hitelességének megitélése kérdéskörben kapott válaszok korrelációja $(n=928)$. Forrás: a szerzô szerkesztése}

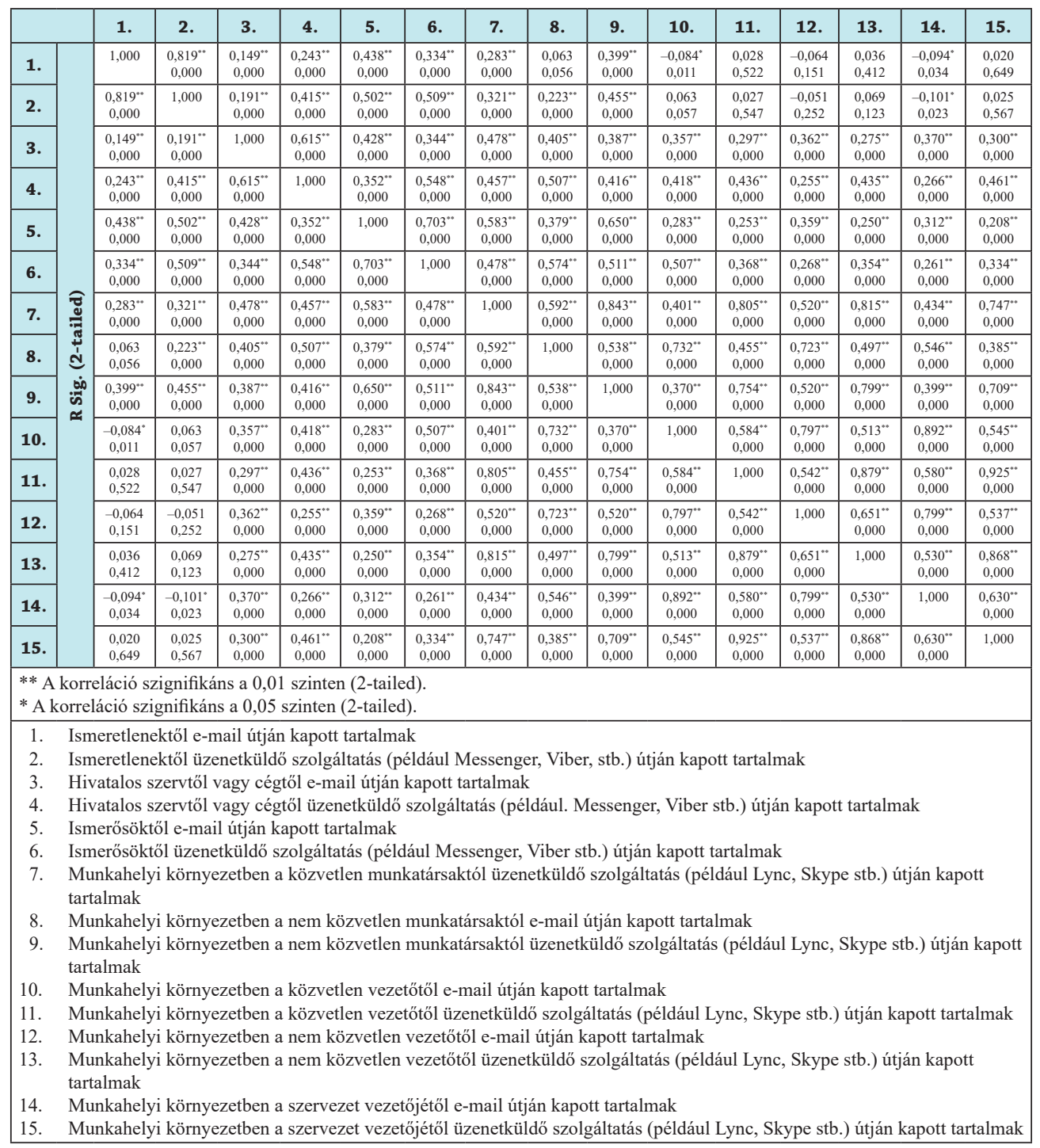

Érdemes összevetni a kapott válaszok korrelációját aszerint is, hogy mely megbízhatósági változók esetén tapasztalunk erős korrelációt a hitelességi változókkal összevetve. Ebben az esetben a munkahelyi környezetben üzenetküldő útján érkezett válaszoknál láthatunk jellemzően erős korrelációt, amely azt jelenti, hogy a kérdőiv kitöltői 
az üzentküldők útján kapott tartalmak megbízhatóságát hasonlóan ítélték meg azok hitelességével. Az e-mail útján érkezett tartalmak megítélésére kapott válaszoknál ugyanakkor csak erősen közepes korreláció $(r$ |0,5|) figyelhető meg.

\section{8. táblázat: A kapott tartalmak megbízhatóságának és hitelességének megitélése kérdéskör-} ben kapott válaszok korrelációja - A sorok a megbizhatósági változók, míg az oszlopokban hitelességi változók szerepelnek $(n=928)$. Forrás: a szerző szerkesztése

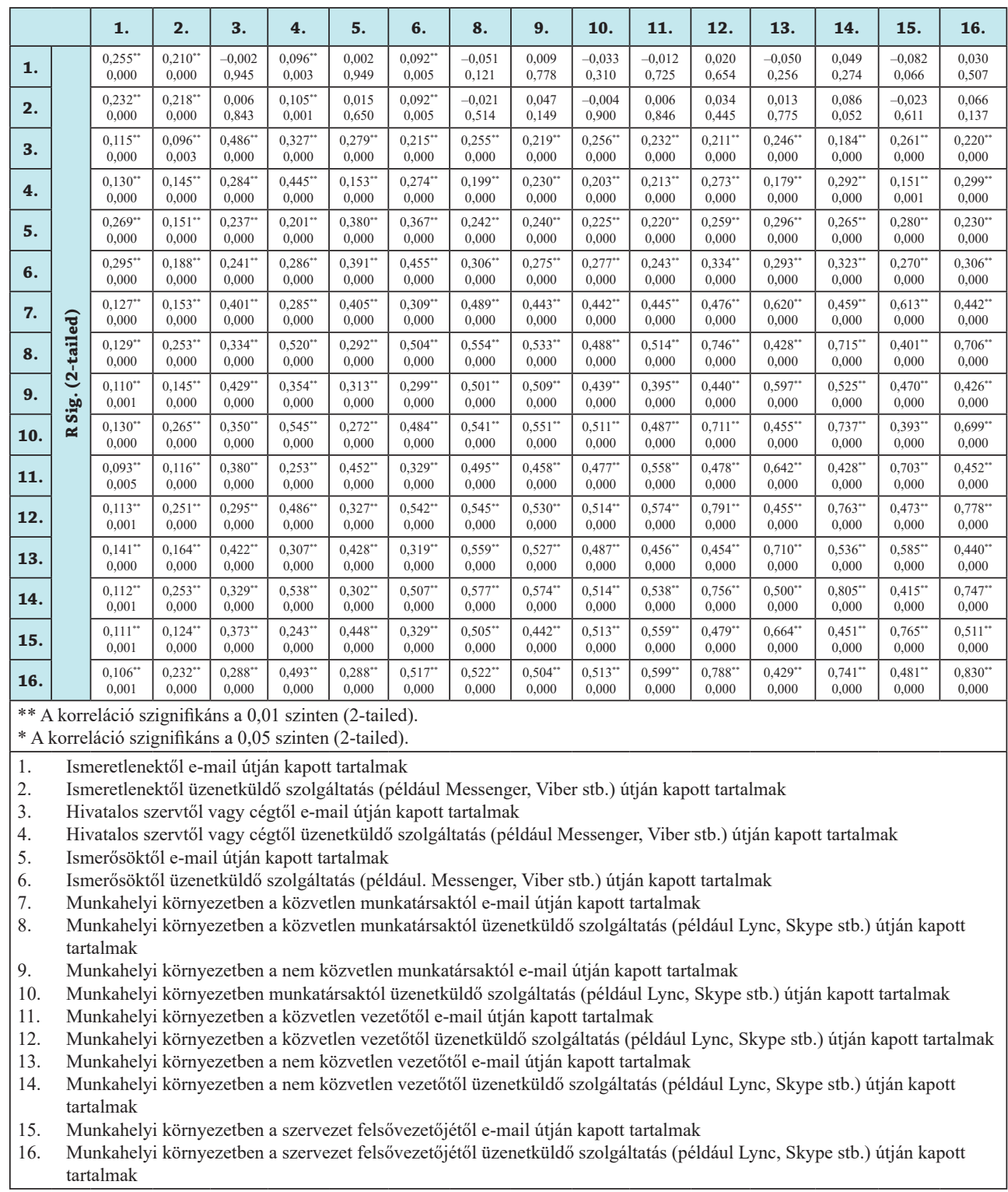


A munkahelyi üzenetküldők megbízhatóságának megítélését egyértelműen befolyásolta, hogy a válaszadó vezető beosztású volt-e vagy sem (M-W közv. munk.: 52075,5, $\mathrm{p}=$ 0,000; M-W nem közv. munk.: 51945,0, p = 0,000; M-W közv. vez.: 51780,5, p=0,000; M-W közv. vez.: 49987, p = 0,000; M-W felsővez.: 51103,5, p = 0,000). Az email útján érkező tartalmak esetén a nem közvetlen vezetőktől érkező tartalmak megbízhatóságának megítélése eltérő a vezetők és beosztottak között. (M-W: 57076 p = 0,033)

A munkahelyi környezetre vonatkozó válaszokat az informatikai végzettség nem befolyásolta, ellenben a privát szféra esetén a hivatalos szervtől kapott e-mail tartalmat leszámítva (M-W: 72734,5, p = 0,718) mindegyik esetnél már eltérést találunk a mintában.

9. táblázat: A kapott tartalmak megbizhatóságának megitélése kérdéskörbe tartozó minták különbözôségének vizsgálata a beosztás, illetve az informatikai végzettség megléte tükrében $(n=928 ; p=0,05)$. Forrás: a szerző szerkesztése

\begin{tabular}{|c|c|c|c|c|c|c|c|c|c|c|c|c|c|c|c|c|c|}
\hline & & 1. & 2. & 3. & 4. & 5. & 6. & 7. & 8. & 9. & 10. & 11. & 12. & 13. & 14. & 15. & 16. \\
\hline $\mathbf{A}$ & चु & $\begin{array}{c}62386,5 \\
0,744\end{array}$ & $\begin{array}{c}61839,0 \\
0,612\end{array}$ & $\begin{array}{c}62459,5 \\
0,783\end{array}$ & \begin{tabular}{|c|}
62071,5 \\
0,697
\end{tabular} & $\begin{array}{c}61703,5 \\
0,602\end{array}$ & $\begin{array}{c}60968,5 \\
0,445\end{array}$ & $\begin{array}{c}61612,0 \\
0,566\end{array}$ & \begin{tabular}{|c}
52075,5 \\
0,000
\end{tabular} & $\begin{array}{c}59937,0 \\
0,261\end{array}$ & \begin{tabular}{|c|}
51945,0 \\
0,000
\end{tabular} & \begin{tabular}{|c|}
59481,0 \\
0,186
\end{tabular} & $\begin{array}{c}51780,5 \\
0,000\end{array}$ & $\begin{array}{c}57076,0 \\
0,033\end{array}$ & \begin{tabular}{|c|}
49987,0 \\
0,000
\end{tabular} & $\begin{array}{c}60188,0 \\
0,287\end{array}$ & $\begin{array}{c}51103,5 \\
0,000\end{array}$ \\
\hline B & 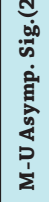 & $\begin{array}{c}66643,5 \\
0,011\end{array}$ & $\begin{array}{c}63186,5 \\
0,000\end{array}$ & $\begin{array}{c}72734,5 \\
0,718\end{array}$ & \begin{tabular}{|c|}
64060,0 \\
0,003
\end{tabular} & $\begin{array}{c}66549,5 \\
0,022\end{array}$ & $\begin{array}{c}63618,0 \\
0,001\end{array}$ & \begin{tabular}{|c}
72898,0 \\
0,757
\end{tabular} & \begin{tabular}{|c}
73392,5 \\
0,888
\end{tabular} & $\begin{array}{c}71369,0 \\
0,436\end{array}$ & \begin{tabular}{|c|}
71784,0 \\
0,522
\end{tabular} & \begin{tabular}{|c|}
72115,5 \\
0,573
\end{tabular} & \begin{tabular}{|c|}
69629,0 \\
0,192
\end{tabular} & $\begin{array}{c}72430,5 \\
0,651\end{array}$ & \begin{tabular}{|c|}
71031,5 \\
0,383
\end{tabular} & \begin{tabular}{|c|}
72414,0 \\
0,644
\end{tabular} & $\begin{array}{c}73702,0 \\
0,964\end{array}$ \\
\hline
\end{tabular}

A: Grouping Variable: Beosztás

B: Grouping Variable: Informatikai végzettséggel rendelkezik

1. Ismeretlenektől e-mail útján kapott tartalmak

2. Ismeretlenektől üzenetküldő szolgáltatás (például Messenger, Viber stb.) útján kapott tartalmak

3. Hivatalos szervtöl vagy cégtöl e-mail útján kapott tartalmak

4. Hivatalos szervtől vagy cégtöl üzenetküldő szolgáltatás (például Messenger, Viber stb.) útján kapott tartalmak

5. Ismerösöktől e-mail útján kapott tartalmak

6. Ismerősöktől üzenetküldő szolgáltatás (például Messenger, Viber stb.) útján kapott tartalmak

7. Munkahelyi környezetben a közvetlen munkatársaktól e-mail útján kapott tartalmak

8. Munkahelyi környezetben a közvetlen munkatársaktól üzenetküldő szolgáltatás (például Lync, Skype stb.) útján kapott tartalmak

9. Munkahelyi környezetben a nem közvetlen munkatársaktól e-mail útján kapott tartalmak

10. Munkahelyi környezetben munkatársaktól üzenetküldő szolgáltatás (például Lync, Skype stb.) útján kapott tartalmak

11. Munkahelyi környezetben a közvetlen vezetőtől e-mail útján kapott tartalmak

12. Munkahelyi környezetben a közvetlen vezetőtöl üzenetküldő szolgáltatás (például Lync, Skype stb.) útján kapott tartalmak

13. Munkahelyi környezetben a nem közvetlen vezetőtől e-mail útján kapott tartalmak

14. Munkahelyi környezetben a nem közvetlen vezetőtől üzenetküldő szolgáltatás (például Lync, Skype stb.) útján kapott tartalmak

15. Munkahelyi környezetben a szervezet felsővezetőjétől e-mail útján kapott tartalmak

16. Munkahelyi környezetben a szervezet felsővezetőjétől üzenetküldő szolgáltatás (például Lync, Skype stb.) útján kapott tartalmak 
A generációk mentén történő minták esetében azt láthatjuk, hogy a megbízhatóság megítélésében a kapott válaszok kizárólag a privát szférát érintő információszerzésnél mutatnak szignifikáns eltérést $\left(\chi^{2}\right.$ ismeretlen e-mail $=11,942, \mathrm{p}=0,008 ; \chi^{2}$ hivatalos üzenet $=11,771, \mathrm{p}=0,008 ; \chi^{2}$ ismerős e-mail $=14,686, \mathrm{p}=0,002 ; \chi^{2}$ ismerős üzenet = 13,308, p = 0,004). Az általános biztonságtudatosság fejlesztése érdekében a későbbiekben érdemes megvizsgálni az egyes generációk által adott válaszokat részletesebben is.

10. táblázat: A kapott tartalmak megbízhatóságának megítélése kérdéskörbe tartozó minták különbözőségének vizsgálata a generációk tükrében $(n=928 ; p=0,05)$. Forrás: a szerzö szerkesztése

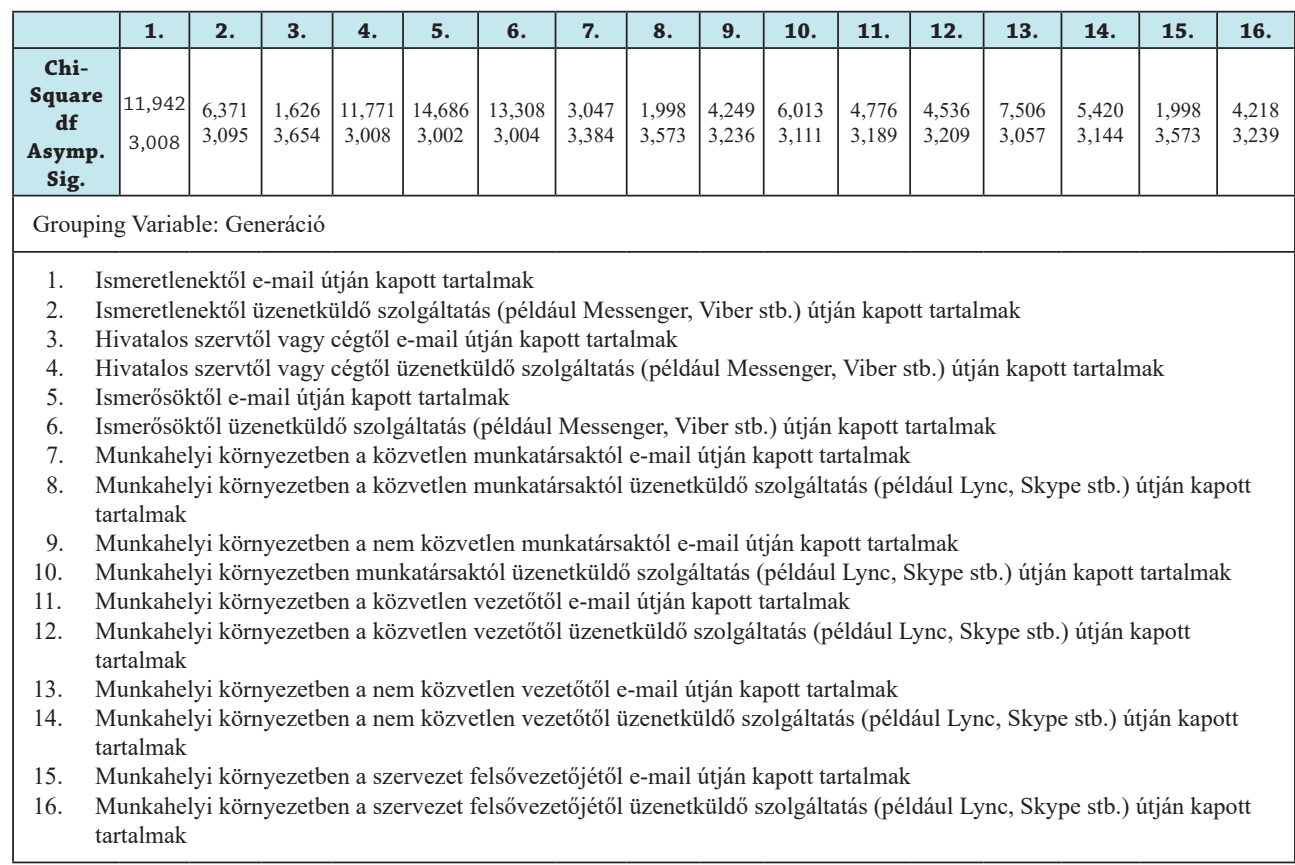

A megbízhatóság mellett érdemes összehasonlítani az egyes mintákat a hitelességet érintő változók mentén is. Ennek során azt láthatjuk, hogy alapvetően a vezetők és a beosztottak a közvetlen munkatárstól e-mail útján (M-W: 56311,5, p = 0,02), a nem közvetlen vezetőtől (M-W: 16345, p = 0,022), illetve a felsővezetőtől ( $\mathrm{M}-\mathrm{W}$ : 16680, $\mathrm{p}=$ 0,044) üzenetküldőn keresztül kapott információk hitelességét ítélték meg szignifikánsan különbözően. 
Az informatikai végzettség a kapott tartalmak hitelességének megítélését nem befolyásolta, a mintákban szignifikáns különbség nem látszik.

11. táblázat: A kapott tartalmak hitelességének megitélése kérdéskörbe tartozó minták különbözőségének vizsgálata a beosztás, illetve az informatikai végzettség megléte tükrében $(n=928 ; p=0,05)$. Forrás: a szerző szerkesztése

\begin{tabular}{|c|c|c|c|c|c|c|c|c|c|c|c|c|c|c|c|c|}
\hline & & 1. & 2. & 3. & 4. & 5. & 6. & 7. & 8. & 9. & 10. & 11. & 12. & 13. & 14. & 15. \\
\hline $\mathbf{A}$ & 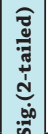 & $\begin{array}{c}62937,0 \\
0,918\end{array}$ & $\begin{array}{c}61553,5 \\
0,577\end{array}$ & \begin{tabular}{|c|}
58545,0 \\
0,108
\end{tabular} & \begin{tabular}{|c|}
57670,5 \\
0,061
\end{tabular} & $\begin{array}{c}62833,0 \\
0,889\end{array}$ & $\begin{array}{c}61783,0 \\
0,625\end{array}$ & $\mid \begin{array}{c}57437,5 \\
0,051\end{array}$ & $\begin{array}{c}56311,5 \\
0,020\end{array}$ & \begin{tabular}{|c|}
58814,0 \\
0,138
\end{tabular} & $\left|\begin{array}{c}57780,5 \\
0,064\end{array}\right|$ & $\begin{array}{c}16832,5 \\
0,058\end{array}$ & $\begin{array}{c}18029,5 \\
0,345\end{array}$ & $\begin{array}{c}16345,0 \\
0,022\end{array}$ & $\begin{array}{c}19074,0 \\
0,958\end{array}$ & $\begin{array}{c}16680,0 \\
0,044\end{array}$ \\
\hline B & 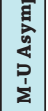 & $\begin{array}{c}68559,5 \\
0,105\end{array}$ & $\begin{array}{c}72953,0 \\
0,785\end{array}$ & $\begin{array}{c}72330,0 \\
0,631\end{array}$ & $\begin{array}{c}73031,0 \\
0,800\end{array}$ & $\begin{array}{c}71623,0 \\
0,485\end{array}$ & $\begin{array}{c}72501,5 \\
0,677\end{array}$ & $\begin{array}{c}73148,5 \\
0,828\end{array}$ & $\begin{array}{c}70904,0 \\
0,360\end{array}$ & $\begin{array}{c}72825,5 \\
0,752\end{array}$ & $\begin{array}{c}72318,0 \\
0,631\end{array}$ & $\begin{array}{c}19988,0 \\
0,095\end{array}$ & $\begin{array}{c}20420,0 \\
0,164\end{array}$ & $\begin{array}{c}20748,5 \\
0,276\end{array}$ & $\begin{array}{c}20511,0 \\
0,189\end{array}$ & $\begin{array}{c}20602,5 \\
0,231\end{array}$ \\
\hline
\end{tabular}

A: Grouping Variable: Beosztás

B: Grouping Variable: Informatikai végzettséggel rendelkezik

1. Ismeretlenektől e-mail útján kapott tartalmak

2. Ismeretlenektől üzenetküldő szolgáltatás (például Messenger, Viber stb.) útján kapott tartalmak

3. Hivatalos szervtől vagy cégtől e-mail útján kapott tartalmak

4. Hivatalos szervtől vagy cégtöl üzenetküldő szolgáltatás (például Messenger, Viber stb.) útján kapott tartalmak

5. Ismerösöktöl e-mail útján kapott tartalmak

6. Ismerősöktől üzenetküldő szolgáltatás (például Messenger, Viber stb.) útján kapott tartalmak

7. Munkahelyi környezetben a közvetlen munkatársaktól üzenetküldő szolgáltatás (például Lync, Skype stb.) útján kapott tartalmak

8. Munkahelyi környezetben a nem közvetlen munkatársaktól e-mail útján kapott tartalmak

9. Munkahelyi környezetben a nem közvetlen munkatársaktól üzenetküldő szolgáltatás (például Lync, Skype stb.) útján kapott tartalmak

10. Munkahelyi környezetben a közvetlen vezetötől e-mail útján kapott tartalmak

11. Munkahelyi környezetben a közvetlen vezetötől üzenetküldő szolgáltatás (például Lync, Skype stb.) útján kapott tartalmak

12. Munkahelyi környezetben a nem közvetlen vezetötöl e-mail útján kapott tartalmak

13. Munkahelyi környezetben a nem közvetlen vezetőtől üzenetküldő szolgáltatás (például Lync, Skype stb.) útján kapott tartalmak

14. Munkahelyi környezetben a szervezet vezetőjétől e-mail útján kapott tartalmak

15. Munkahelyi környezetben a szervezet vezetőjétől üzenetküldő szolgáltatás (például Lync, Skype stb.) útján kapott tartalmak

Korábban láthattuk, hogy az elérhető információk hitelességének megítélésében az egyes generációs minták mentén eltérés volt tapasztalható. Ugyanez az eltérés azonban a kapott információk hitelességének megítélése esetén már nem áll fenn. Egyedül az ismeretlenektől kapott tartalmaknál láthatunk a kapott mintában szignifikáns különbözőséget, 
függetlenül attól, hogy az információ e-mail útján $\left(\chi^{2}=22,905, \mathrm{p}=0,000\right)$ vagy üzenetküldő szolgáltatás $\left(\chi^{2}=9,231, p=0,026\right)$ segítségével érkezik.

12. táblázat: A kapott tartalmak hitelességének megitélése kérdéskörbe tartozó minták különbözooségének vizsgálata a generációk tükrében $(n=928 ; p=0,05)$. Forrás: a szerzô szerkesztése

\begin{tabular}{|c|c|c|c|c|c|c|c|c|c|c|c|c|c|c|c|}
\hline & 1. & 2. & 3. & 4. & 5. & 6. & 7. & 8. & 9. & 10. & 11. & 12. & 13. & 14. & 15. \\
\hline $\begin{array}{l}\text { Chi- } \\
\text { Square }\end{array}$ & 22,905 & 9,231 & 4,464 & 3,341 & 5,386 & 4,555 & 1,421 & 3,272 & 0,539 & 5,261 & 3,060 & 2,548 &, 740 & 4,302 & 3,454 \\
\hline df & 3 & 3 & 3 & 3 & 3 & 3 & 3 & 3 & 3 & 3 & 3 & 3 & 3 & 3 & 3 \\
\hline $\begin{array}{l}\text { Asymp. } \\
\text { Sig. }\end{array}$ & 0,000 & 0,026 & 0,216 & 0,342 & 0,146 & 0,207 & 0,701 & 0,351 & 0,910 & 0,154 &, 382 & 0,467 & 0,864 & 0,231 & 0,327 \\
\hline \multicolumn{16}{|c|}{ Grouping Variable: Generáció } \\
\hline \multicolumn{16}{|c|}{ 1. Ismeretlenektől e-mail útján kapott tartalmak } \\
\hline 2. I & \multicolumn{15}{|c|}{ Ismeretlenektől üzenetküldő szolgáltatás (például Messenge } \\
\hline 3. $\mathrm{H}$ & \multicolumn{15}{|c|}{-mail útján kapott tartalmak } \\
\hline 4. $\mathrm{H}$ & \multirow{2}{*}{\multicolumn{15}{|c|}{$\begin{array}{l}\text { Hivatalos szervtől vagy cégtől üzenetküldő szolgáltatás (pél } \\
\text { Ismerösöktől e-mail útián kapott tartalmak }\end{array}$}} \\
\hline 5. I & & & & & & & & & & & & & & & \\
\hline 6. I & \multicolumn{15}{|c|}{ Ismerősöktől üzenetküldő szolgáltatás (például Messenger, Viber stb.) útján kapott tartalmak } \\
\hline 7. $\begin{array}{ll}1 \\
\mathrm{t}\end{array}$ & \multicolumn{15}{|c|}{$\begin{array}{l}\text { Munkahelyi környezetben a közvetlen munkatársaktól üzenetküldő szolgáltatás (például Lync, Skype stb.) útján kapott } \\
\text { tartalmak }\end{array}$} \\
\hline 8. 1 & \multicolumn{15}{|c|}{ Munkahelyi környezetben a nem közvetlen munkatársaktól e-mail útján kapott tartalmak } \\
\hline 9. $\quad \mathrm{N}$ & \multicolumn{15}{|c|}{$\begin{array}{l}\text { Munkahelyi környezetben a nem közvetlen munkatársaktól üzenetküldő szolgáltatás (például Lync, Skype stb.) útján } \\
\text { kapott tartalmak }\end{array}$} \\
\hline 10. $\mathrm{N}$ & \multicolumn{15}{|c|}{ Munkahelyi környezetben a közvetlen vezetőtől e-mail útján kapott tartalmak } \\
\hline 11. $\begin{array}{ll}\mathrm{N} \\
\mathrm{t}\end{array}$ & \multicolumn{15}{|c|}{$\begin{array}{l}\text { Munkahelyi környezetben a közvetlen vezetőtől üzenetküldő szolgáltatás (például Lync, Skype stb.) útján kapott } \\
\text { tartalmak }\end{array}$} \\
\hline 12. & \multicolumn{15}{|c|}{ Munkahelyi környezetben a nem közvetlen vezetőtől e-mail útján kapott tartalmak } \\
\hline 13. $\mathrm{t}$ & \multirow{2}{*}{\multicolumn{15}{|c|}{$\begin{array}{l}\text { Munkahelyi környezetben a nem közvetlen vezetőtől üzenetküldő szolgáltatás (például Lync, Skype stb.) útján kapott } \\
\text { tartalmak }\end{array}$}} \\
\hline 14. $\mathrm{N}$ & \multicolumn{7}{|c|}{ Munkahelyi környezetben a szervezet vezetőjétől e-mail útján kapott tartalmak } & & & & & & & & \\
\hline 15. $\quad \mathrm{l}$ & \multicolumn{15}{|c|}{$\begin{array}{l}\text { Munkahelyi környezetben a szervezet vezetőjétől üzenetküldő szolgáltatás (például Lync, Skype stb.) útján kapott } \\
\text { tartalmak }\end{array}$} \\
\hline
\end{tabular}

\section{Következtetések}

Információvédelmi szempontból nagyon fontos, hogy megfelelő és komplex képzési programot alakítsanak ki, amelynek keretében az információ megbízhatóságának és a hitelességének megítélését is célirányosan fejleszteni kell. Ennek érdekében célszerü figyelembe vennünk az alábbi következtetéseket:

- Az információ megbízhatóságának és hitelességének megítélésében sem a privát, sem pedig a hivatali közegben nem kaptunk kiemelkedően magas átlagértékeket.

- A kapott információ hitelességének és megbízhatóságának a megítélése sokkal inkább függ magától a közvetítő csatornától, mintsem a küldő személyétől. 
- A munkatársak informatikai végzettsége kevésbé volt befolyásoló tényező a munkahelyi környezetben történő megítélések terén. A vezető beosztás is egyértelműen az üzenetküldő szolgáltatásokon keresztül érkező tartalmak esetén volt befolyásoló tényező.

- A kapott információ megítélése egységesebb volt generációs szempontból, mint az információs felületeken elérhető tartalmak megítélése, hiszen azok hitelességét az egyes generációk eltérően értékelték.

\section{IRODALOMJEGYZÉK}

Desikan, Prasanna - Delong, Colin - Beemanapalli, Kalyan - Bose, Amit - Strivastava, Jaideep (2006): Web Mining For Self-directed E-learning. In Morales, C. Romero - Ventura, S. eds.: Data Mining in E-Learning. Southampton, Boston, WITPress. 21-37. Forrás: https://pdfs.semanticscholar.org /3ff0/86111c75550ce67658ebbdf28be410551abc.pdf (2020. 01. 21.)

Hollik Ildikó - Ősz Rita (2016): Bevezetés a pedagógia kutatásmódszertanba. Budapest, Typotop Kft.

Khan, Bilal - Alghathbar, Khaled S. - Nabi, Syead Ifran - Khan, Muhammad Khurram (2011): Effectiveness of information security awareness methods based on psychological theories. African Journal of Business Management, Vol. 5, No. 26. 10862-10868. DOI: https://doi.org/10.5897/ AJBM11.067

Klösgen, Willi - Zytkow, Jan M. (2002): Handbook of Data Mining and Knowledge Discovery. New York, Oxford University Press Inc.

Meretei Barbara (2017): Generációs különbségek a munkahelyen. Vezetéstudomány, 48. évf. 10. sz. 10-18. DOI: https://doi.org/10.14267/VEZTUD.2017.10.02

Muha Lajos (2008): Az informatikai biztonság egy lehetséges rendszertana. Bolyai Szemle, 17. évf. 4. sz. 137-156.

Nyikes Zoltán (2016): A biztonságtudatosság a digitális kompetencia tükrében. Kolozsvár, Erdélyi Múzeum-Egyesület. 313-316. DOI: https://doi.org/10.33895/mtk-2016.05.69

Pintér Róbert (2007): Úton az információs társadalom megismerése felé. In Pintér Róbert szerk.: Az információs társadalom - Az elmélettól a politikai gyakorlatig. Budapest, Gondolat - Új Mandátum.

Tari Annamária (2010): Y generáció. Budapest, Jaffa Kiadó.

Wilson, Mark - Hash, Joan (2003): Building an information technology security awareness and training program. NIST Special publication. DOI: https://doi.org/10.6028/NIST.SP.800-50

\section{Jogforrás}

2013. évi L. törvény az állami és önkormányzati szervek elektronikus információbiztonságáról

\section{Internetes források}

Kissné András Klára (2014): Lehet-e egységesen motiválni a különböző generációs munkaeröt? Forrás: www. hrportal.hu/hr/lehet-e-egysegesen-motivalni-a-kulonbozo-generacios-munkaerot-20140130.html (2020. 01. 21.)

Security Awareness Planning Kit (2016). Forrás: https://securingthehuman.sans.org/resources/planning (2020. 01. 21.)

Survey on Internet Security Awareness (2009). Forrás: www.kansai-u.ac.jp/riss/en/shareduse/data/17_E_questionnaire.pdf (2020.01. 21.) 


\section{ABSTRACT \\ Attitude Investigation in the National Tax and Customs Administration about the Credibility and Reliability of Information}

DUCHON Jenő

There was a questionnaire survey among the employees of the NTCA. The goal with this survey was that we receive a snapshot of the state of information security awareness of the colleagues. Within this research we tried to examine the employees' opinion about the information authenticity and reliability depending on the source of information. This study summarises the results of this survey in order to provide feedback to a complex information security awareness program.

Keywords: information authenticity, information reliability, information security awareness, attitude research 